\title{
Phenolic Composition of Basil Plants Is Differentially Altered by Plant Nutrient Status and Inoculation with Mycorrhizal Fungi
}

\author{
Carolyn F. Scagel ${ }^{1}$ \\ USDA-ARS-Horticultural Crops Research Unit, 3420 NW Orchard Street, \\ Corvallis, OR 97330
}

Jungmin Lee

USDA-ARS-Horticultural Crops Research Unit Worksite, Parma, ID 83660

Additional index words. Ocimum basilicum, phenolics, Rhizophagus (Glomus) intraradices, arbuscular mycorrhizal fungi, plant nutrition, phosphorus

\begin{abstract}
Four cultivars of basil (Ocimum basilicum L. 'Cinnamon', 'Siam Queen', 'Sweet Dani', and 'Red Rubin') were inoculated or not with the arbuscular mycorrhizal fungus (AMF), Rhizophagus (formerly Glomus) intraradices (Schenck \& Smith) Walker \& Schüßler and grown with a fertilizer containing either $64 \mathrm{mg} \cdot \mathrm{L}^{-1}$ phosphorus (P) (low $P$ ) or $128 \mathrm{mg} \cdot \mathrm{L}^{-1} \mathrm{P}$ (high $\mathrm{P}$ ) to assess whether 1) $\mathrm{P}$ availability and inoculation with $\mathrm{AMF}$ influences the phenolic composition of basil; and 2) treatment effects on phenolic composition are related to plant nutrient status. Growth, root colonization by AMF, anthocyanins, total phenolics, specific polyphenolics, and mineral nutrients were measured after 16 weeks of growth. Non-inoculated plants were not colonized by AMF. AMF colonization of inoculated plants was not influenced by $P$ rate. Increased $P$ rate and $A M F$ inoculation increased biomass. Increased $P$ rate enhanced (increased concentration and content) $P$ and calcium (Ca) uptake and AMF inoculation enhanced nitrogen $(N)$, potassium $(K)$, sulfur $(\mathrm{S})$, boron $(\mathrm{B})$, iron (Fe), and zinc ( $\mathrm{Zn})$ uptake. Increased or decreased uptake (content) of other nutrients between $P$ rates and AMF treatments were related to differences in biomass (e.g., similar or lower concentration). Treatment effects on phenolic accumulation were related to the effects of $P$ rate and AMF on 1) plant growth; 2) nutrient uptake; and 3) other factors not directly related to measured differences in nutrient uptake or plant growth. Differences between treatments in rosmarinic acid, the predominant polyphenolic produced by all cultivars, were related to the effects of $P$ rate and AMF on plant growth. Both increased $P$ rate and AMF inoculation enhanced production (increased concentration and content) of chicoric acid and caffeic acid derivative. Increased $P$ rate and inoculation with AMF differentially enhanced production of several other minor polyphenolics resulting in plants with different polyphenolic profiles. Results indicate that AMF inoculation may be an additional strategy for optimizing basil quality in terms of polyphenolic production and composition beyond benefits obtained from just altering plant nutrient status or selecting specific cultivars.
\end{abstract}

Many plant species in the Lamiaceae (mint family), including basil (Ocimum basilicum), contain high amounts of phenolics (Dragland et al., 2003; Gutierrez et al., 2008; Hussain et al., 2008; Javanmardi et al., 2002; Lee, 2010; Yanishlieva et al., 2006). Basil has a high market demand and economically important

\footnotetext{
Received for publication 1 Mar. 2012. Accepted for publication 26 Mar. 2012.

This research was funded under USDA-ARS CRIS \#5358-12210-003-00D and \#5358-21000-041-00D. We gratefully acknowledge Jesse Mitchell, Suean Ott, Chris Rennaker, Lisa Tribbet, and Hugh Jepson of the USDA-ARS for technical assistance.

Mention of trade names or commercial products in this publication is solely for the purpose of providing specific information and does not imply recommendation or endorsement by the U.S. Department of Agriculture.

${ }^{1}$ To whom reprint requests should be addressed; e-mail Carolyn.Scagel@ars.usda.gov.
}

uses in culinary applications, food flavorings, preservatives, and cosmetic, pharmaceutical, and industrial products (Brewer, 2011; Makri and Kintzios, 2007). Quality of basil used in certain fresh and dry products is a function of its production of secondary metabolites, including phenolics (Hossian et al., 2010; Lee, 2010) and essential oils (Copetta et al., 2006; Hussain et al., 2008).

The main phenolics reported in basil plants are in the classes of phenolic acids and flavonolglycosides, some of which have potential human health benefits (Hossian et al., 2010; Javanmardi et al., 2002; Jayasinghe et al., 2003; Lee and Scagel, 2009, 2010; Nguyen and Niemeyer, 2008). Rosmarinic, chicoric, and caftaric acids are the major phenolic acids typically present in basil (Kwee and Niemeyer, 2011; Lee and Scagel, 2009). Most research on secondary metabolite production in basil only reports concentration data from leaves although stems are incorporated into many consumer products (Kwee and Niemeyer, 2011; Lee and Scagel, 2010).

Chemical composition of basil depends on many factors, including cultural practices, growth phase at harvest, storage conditions, and environmental influences during production (Hussain et al., 2008). Studies of environmental effects on phenolic content of herb plants are limited (Freire et al., 2006; Nell et al., 2009; Yi and Wetzstein, 2010, 2011). Many secondary metabolites, including phenolics, are involved in several plant responses to biotic and abiotic stimuli (Li et al., 2007, 2010; Vogt, 2010). Phosphorus is required for the biosynthesis of secondary metabolites (Malusà et al., 2006) and therefore $P$ availability to plants may also alter phenolic composition. The synthesis of phenolics competes directly with the synthesis of proteins required for growth (Haukioja et al., 1998). Most research examining the influence of plant nutrition on phenolic production in basil has reported concentrations in aerial structures and has not assessed the relationships between nutrient uptake, per se, and phenolic production or have not considered how growth influences interpretation of concentration data (Lee and Scagel, 2009; Nguyen et al., 2010; Nguyen and Niemeyer, 2008).

Root colonization by AMF can alter plant biomass, nutrient status, and carbon use and therefore may also alter the production and composition of secondary metabolites in plants (Copetta et al., 2006; Fester et al., 1999; Strack and Fester, 2006; Strack et al., 2003; Toussaint et al., 2007). The relationship between AMF colonization and the phenolics produced in plant shoots is not well understood (Geneva et al., 2010; Toussaint, 2007; Yao et al., 2007). Quantitative and qualitative changes in phenolic composition of plants colonized by AMF could have significant effects on quality of basil fresh and dry products.

There has been much research on the role of AMF in plant productivity and ecosystem function as a result of enhanced nutrient acquisition and improved ability to tolerate abiotic and biotic stresses (Gianinazzi et al., 2010). Little research has illuminated how AMF can also alter plant product qualities. Phenolic production in plants can be affected by biotic and abiotic factors and AMF colonization may be one way to alter or enhance phenolic production or composition within the host plant (Ganz et al., 2002; Toussaint et al., 2007). We evaluated whether the influence of AMF on production of phenolics in basil is related to AMF-mediated effects on whole plant nutrient status.

\section{Materials and Methods}

Plant materials and arbuscular mycorrhizal fungus inoculum. Four basil cultivars (Cinnamon, Siam Queen, Sweet Dani, and Red Rubin; Territorial Seed Company, Cottage Grove, OR) were used to examine the effect of inoculation with AMF on plant nutrient uptake and phenolic production. The AMF, Rhizophagus intraradices, originally obtained from a commercial inoculum producer as Glomus 
intraradices Schenck \& Smith (Native Plants Incorporated, Salt Lake City, UT), was propagated in pot cultures on roots of bunching onion (Allium cepa L. 'White Lisbon') grown in a 1:1 mixture of Willamette Valley alluvial silt loam and river sand $\left(8 \mathrm{mg} \cdot \mathrm{kg}^{-1}\right.$ available $P$, $\mathrm{pH}$ 6.3) for 5 months. Inoculum consisted of a mixture of the soil substrate, extraradical hyphae and spores, and colonized root segments (less than $2 \mathrm{~mm}$ in length). Propagule numbers (15 propagules/g of soil substrate) in the inoculum used in this study were estimated using the MPN (most probable number) method (Woomer, 1994).

Plant culture and treatments. Surfacesterilized (30\% sodium hypochlorite for $10 \mathrm{~min}$ followed by a sterile water rinse) basil seeds were sown in 0.92-L containers (Gauge Dura Pot \#GDP400; Gauge Industries, Lake Oswego, OR) containing a steam-pasteurized $\left(60^{\circ} \mathrm{C}\right.$ for $30 \mathrm{~min}$ ) 3:1 mixture of Willamette Valley alluvial silt loam and vermiculite (Horticultural Vermiculite; SunGro Horticulture, Bellevue, WA). Available $\mathrm{P}$ in the growing substrate was $3 \mathrm{mg} \cdot \mathrm{kg}^{-1}$, and $\mathrm{pH}$ was 6.2 . Half of the plants were inoculated with AMF by handmixing $50 \mathrm{~g}$ of the AMF inoculum into the growing substrate in each pot before sowing seeds (AMF treatment) and the same quantity of sterile $\left(121{ }^{\circ} \mathrm{C}, 15 \mathrm{~min}\right)$ inoculum was mixed into the growing substrate for the remainder of the plants before sowing seeds (non-inoculated treatment) (20 plants per cultivar per AMF treatment). Containers were placed in a glass greenhouse and watered as needed. Supplemental light $\left(.720 \mu \mathrm{mol} \cdot \mathrm{m}^{-2} \cdot \mathrm{s}^{-1}\right.$ photosynthetically active radiation) was provided for $16 \mathrm{~h} \cdot \mathrm{d}^{-1}$ by high-pressure multivapor lamps. Day/night temperatures were controlled at $24 / 15^{\circ} \mathrm{C}$ during the experiment. After cotyledons had fully expanded, plants were fertilized weekly with $50 \mathrm{~mL}$ of a liquid fertilizer containing either $64 \mathrm{mg} \cdot \mathrm{L}^{-1} \mathrm{P}$ (low $\mathrm{P}$ ) or $128 \mathrm{mg} \cdot \mathrm{L}^{-1} \mathrm{P}$ (high $\mathrm{P}$ ) and $380 \mathrm{mg} \cdot \mathrm{L}^{-1} \mathrm{~N}$, $380 \mathrm{mg} \cdot \mathrm{L}^{-1} \mathrm{~K}, 64 \mathrm{mg} \cdot \mathrm{L}^{-1} \mathrm{~S}, 100 \mathrm{mg} \cdot \mathrm{L}^{-1} \mathrm{Ca}$, $36 \mathrm{mg} \cdot \mathrm{L}^{-1}$ magnesium $(\mathrm{Mg}), 4.6 \mathrm{mg} \cdot \mathrm{L}^{-1} \mathrm{Fe}$, $18 \mathrm{mg} \cdot \mathrm{L}^{-1}$ chlorine, $0.55 \mathrm{mg} \cdot \mathrm{L}^{-1}$ manganese (Mn), $0.37 \mathrm{mg} \cdot \mathrm{L}^{-1} \mathrm{~B}, 0.024 \mathrm{mg} \cdot \mathrm{L}^{-1} \mathrm{Zn}, 0.06$ $\mathrm{mg} \cdot \mathrm{L}^{-1}$ copper $(\mathrm{Cu})$, and $0.006 \mathrm{mg} \cdot \mathrm{L}^{-1} \mathrm{mo}-$ lybdenum (10 plants per cultivar per AMF treatment per $P$ treatment). Plants were pruned back, to three nodes, 6weeks after germination and inflorescences that began to develop 9 weeks after germination were removed from plants.

Plant harvest and colonization assessment. All plants were destructively harvested 16 weeks after germination and separated by structure: leaves, stems, or roots. Growing substrate was removed from roots by washing and fresh weight of each structure was recorded. Fresh samples $(\mathrm{n}=5)$ of each structure from each cultivar by treatment combination were frozen, liquid N-powdered, extracted, and analyzed for phenolic composition as described in detail previously (Lee and Scagel, 2009, $2010)$. Fresh subsamples $(n=10)$ of roots were weighed, cleared, and stained using a modified procedure of Philips and Hayman (1970), in which lacto-phenol was replaced with lacto-glycerin and assessed for AMF colonization. AMF colonization was measured on $\approx 1-\mathrm{cm}$ sections of root samples using the Bierman and Linderman (1980) method. Fresh samples $(n=5)$ of each structure were dried at $65^{\circ} \mathrm{C}$ in a forced-air oven, weighed, ground to pass through a 40-mesh screen, and analyzed for nutrient composition (Scagel et al., 2007).

Nutrient analyses. Dried samples were analyzed for concentrations ( $\mathrm{mg} \cdot \mathrm{g}^{-1}$ dry weight) of carbon (C) and $\mathrm{N}$ by combustion (Tru Spec CHN; LECO Corp., St. Joseph, MI) (Scagel et al., 2007) and concentrations (mg. $\mathrm{g}^{-1}$ dry weight) of other macro- and micronutrients by inductively coupled plasma-optical emission spectroscopy (Perkin-Elmer Optima 3000, Wellesley, MA) after nitric acid digestion (Scagel et al., 2008). Standard reference apple leaves (\#151; National Institute of Standards and Technology, Gaithersburg, MD) were run with samples for all procedures to ensure accuracy of results with $\pm 3 \% \mathrm{CV}$.

Phenolic analyses. Aqueous extracts were analyzed for concentration of total anthocyanins (ACY) and total phenolics (TP). These extracts were further purified with a Sep-Pak Plus $\mathrm{C}_{18}$ mini column (Waters Corp., Milford, MA; Lee and Finn, 2007) before individual phenolics other than anthocyanins (polyphenolics) analysis. Using a SpectraMax M2 microplate reader (Molecular Devices Corp., Sunnyvale, CA), absorbance at $520 \mathrm{~nm}$ and $700 \mathrm{~nm}$ was used to determine ACY (mg cyanidin-glucoside/g fresh weight) (Lee et al., 2005) and absorbance at $765 \mathrm{~nm}$ was used to determine TP (mg gallic acid/g fresh weight) (Waterhouse, 2002) in duplicate measurements for each sample. Specific polyphenolics were determined using an high-performance liquid chromatography/diode array detector (HPLC/DAD) (HP1100; Agilent Technologies, Inc., Palo Alto, CA) and HPLC/DAD/ electrospray ionization-tandem mass spectroscopy (MS was a XCT ion trap mass spectrometer; Agilent Technologies, Inc.) system (Lee and Finn, 2007). Phenolic acids were quantified as caffeic acid equivalents at $320 \mathrm{~nm}$ and flavonol-glycosides were quantified as quercetin-rutinoside equivalents at $370 \mathrm{~nm}$ based on external standards. Polyphenolics were identified based on ultravioletvisible spectra, retention time, authentic standards (caffeic acid, chicoric acid, quercetinrutinoside, and rosmarinic acid), molecular ions, and fragmentation ions. Peak identification is detailed in Lee and Scagel $(2009,2010)$ and abbreviated by P1 through P11: caffeic acid derivative ( $\mathrm{P} 1$; not detected in samples from this study), caftaric acid (P2), cinnamyl malic acid (P3), feruloyl tartaric acid (P4), caffeic acid (P5), caffeic acid derivative (P6), chicoric acid (P7), caffeic acid derivative (P8), quercetin-rutinoside (P9), cinnamic acid derivative $(\mathrm{P} 10)$, and rosmarinic acid (P11).

Calculations. Total fresh and dry biomasses were calculated as the sum of fresh and dry weights, respectively, over all structures. Biomass allocation between different structures (e.g., roots, stems, leaves) was calculated as the percentage $(\%)$ of total fresh or dry biomass in each structure. The nutrient and phenolic content of each plant structure was calculated by multiplying the compound concentration in each structure by the dry (nutrients) or fresh (phenolics) mass of each structure. Net nutrient uptake and phenolic production were calculated as the sum content for each nutrient and phenolic overall structures. Shoot accumulation of nutrients and phenolics were calculated as the sum content for each nutrient and phenolic in leaves and stems. Minor polyphenolics (MPP) were calculated as the sum of phenolic peaks P2 through P8 and P10.

Statistical analyses. Containers were arranged in a randomized design with each treatment unit (container) replicated 10 times for each AMF treatment (non-inoculated, AMF-inoculated) and $\mathrm{P}$ treatment (low $\mathrm{P}$, high $\mathrm{P}$ ) for each cultivar. All statistical analyses were performed using Statistica ${ }^{\circledR}$ (Statsoft, Inc., Tulsa, OK). Data were tested for homogeneity of variance (Levene's test) and normality (Kolmogoro-Smirnov test). Root colonization by AMF and biomass allocation data were arcsin-transformed before analyses and backtransformed means are presented. ACY data were analyzed by cultivar using the Kruskal-Wallis analysis of variance (ANOVA) and median test and means were separated at $P \leq 0.05\left(\mathrm{~K}-\mathrm{W}_{0.05}\right)$. All other data were analyzed using mixed-model ANOVA with cultivar, AMF treatment, and $\mathrm{P}$ treatment as main effects and cultivar considered a random effect. Non-inoculated plants were not colonized by AMF (Table 1); therefore, only cultivar and $P$ treatment were used in analysis of AMF colonization data. Eta-squared $\left(\eta^{2}\right)$ was used to determine the proportion of total variability attributable to differences among cultivars $\left(\eta^{2}\right)$ or treatments (AMF inoculation, $\eta_{A}^{2}$; P rate, $\eta_{P}^{2}$ ). When appropriate, based on ANOVA results, means were compared using Tukey's honestly significant difference test at $P \leq 0.05\left(\mathrm{THSD}_{0.05}\right)$ for main

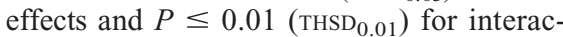
tions. Relationships between whole plant net nutrient uptake and 1) whole plant production; 2) shoot accumulation; and 3) root accumulation of phenolics were assessed using Spearman's rank order correlation coefficient $(R)$ at $P \leq 0.05$

Data interpretation. After ANOVA, plant composition (nutrients, phenolics) data were graphically analyzed using vector analysis, a technique that allows for simultaneous comparison of plant growth and nutrient or phenolic concentration and content (Haase and Rose, 1995; Swift and Brockley, 1993; Valentine and Allen, 1990). Composition data for plants growing in different $\mathrm{P}$ rate and AMF inoculation treatments were compared after normalization using low $\mathrm{P}$ or non-AMF as the control treatment. A combination of significantly greater biomass, concentration, and content of a specific nutrient or phenolic was interpreted as enhanced whole plant net nutrient uptake and phenolic production or enhanced accumulation in shoots (stems and leaves) and roots. In contrast, the combination of significantly lower concentration and content was interpreted as suppressed whole plant net uptake or production or suppressed accumulation in 
Table 1. Dry and fresh biomass and biomass allocation in 16-week-old, greenhouse-grown 'Cinnamon' (CN), 'Sweet Dani' (SD), 'Siam Queen' (SQ), and 'Red Rubin' (RR) basil plants grown with a complete fertilizer containing $16 \mathrm{mg} \cdot \mathrm{L}^{-1}(\mathrm{LP})$ or $32 \mathrm{mg} \cdot \mathrm{L}^{-1}$ (HP) phosphorus (P) fertilizer and inoculated (AMF) or not (non-AMF) with the arbuscular mycorrhizal fungus (AMF), Rhizophagus intraradices.

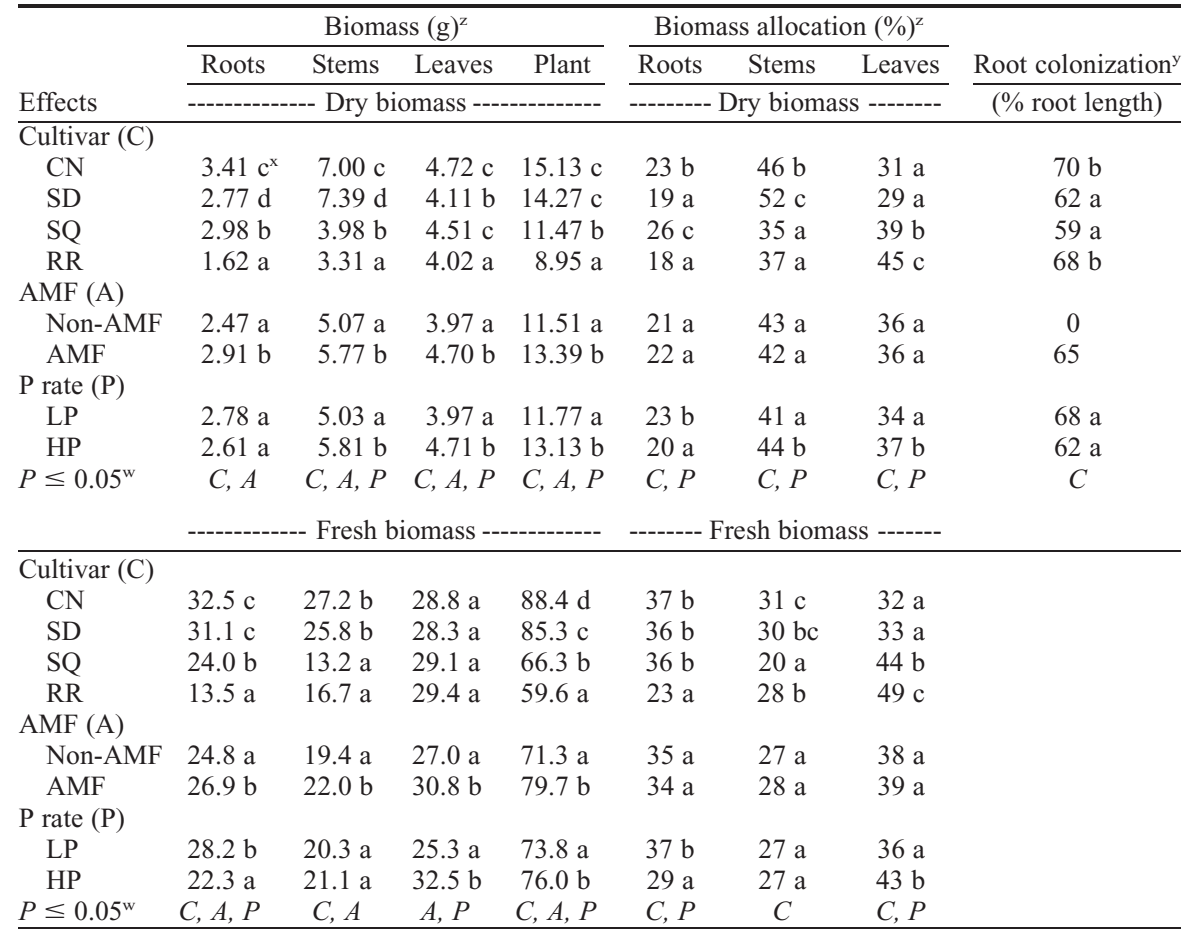

${ }^{\mathrm{z}}$ Dry and fresh biomass and biomass allocation (\% of total plant biomass). Dry biomass $=$ plant structures oven-dried at $35^{\circ} \mathrm{C}$ before nutrient analyses (cultivar, $\mathrm{n}=20$; AMF and $\mathrm{P}$ rate, $\mathrm{n}=40$ ). Fresh biomass $=$ plant structures before freezing for phenolic analyses (cultivar, $\mathrm{n}=12$; AMF and $\mathrm{P}$ rate, $\mathrm{n}=24$ ).

y Proportion of root length containing structures of AMF (cultivar, $\mathrm{n}=10$; $\mathrm{P}$ rate, $\mathrm{n}=20$ ).

${ }^{\mathrm{x}}$ Means within a column and effect followed by the same lower case letter are not significantly different at $P \leq 0.05$ using Tukey's honestly significant difference.

${ }^{\text {w Significant }}(P \leq 0.05)$ effects for cultivar $(\mathrm{C}), \mathrm{AMF}$ treatment $(\mathrm{A}), \mathrm{P}$ rate $(\mathrm{P})$. There were no significant interactions between main effects.

shoots or roots. When only concentration or content was significantly different between AMF or $\mathrm{P}$ rate treatments, differences were considered to be a function of plant size or growth (e.g., lower concentration resulting from dilution, greater content resulting from growth). For example, a combination of greater biomass, similar or lower concentration, and greater content was interpreted as greater whole plant net uptake, production, or accumulation in shoots and roots. A combination of greater biomass, lower concentration, and similar content was interpreted as similar whole plant net uptake and production or accumulation in shoots and roots.

\section{Results}

Root colonization. Root colonization by AMF was greatest in 'Cinnamon' and 'Red Rubin' and lowest in 'Sweet Dani' and 'Siam Queen' (Table 1). Variation among cultivars accounted for a large proportion of the total variation in root colonization $\left(\eta_{C}^{2}>0.77\right)$. On average, $65 \%$ of root length in AMFinoculated plants contained AMF. Phosphorus application rate had no influence on AMF colonization.

Biomass and biomass allocation. Plants of 'Cinnamon' and 'Sweet Dani' had greater biomass than 'Siam Queen', and 'Siam Queen' had greater biomass than 'Red Rubin' (Table 1). Variation among cultivars accounted for greater than $70 \%$ of variation in root, stem, and total plant biomass $\left(\eta_{C}^{2}>0.70\right)$. Biomass variation among cultivars was lower for leaves $\left(\eta_{C}^{2}>\right.$ 0.25 ) than stems and roots. Plants of 'Red Rubin' and 'Sweet Dani' allocated the greatest proportion of total biomass to shoots (Table 1). Variation among cultivars accounted for greater than $68 \%$ of variation in biomass allocation to leaves and stems. Biomass allocation variation among cultivars was lower for roots $\left(\eta_{C}^{2}>0.53\right)$ than stems and leaves.

Inoculation with AMF increased shoot, root, and total plant biomass (Table 1). Biomass variation between AMF treatments was greater for leaves $\left(\eta_{A}{ }^{2}>0.24\right)$ than stems and roots $\left(\eta_{A}{ }^{2}>0.18\right)$. Increased $\mathrm{P}$ rate increased shoot and total plant biomass (Table 1). Biomass variation between $P$ rates was greater for leaves $\left(\eta_{P}^{2}>0.26\right)$ than stems $\left(\eta_{P}^{2}>0.05\right)$. Inoculation with AMF had no influence on biomass allocation (Table 1). Increased $P$ rate increased biomass allocation to shoots and decreased biomass allocation to roots. Biomass allocation variation between $\mathrm{P}$ rates was greater for roots $\left(\eta_{P}^{2}>0.29\right)$ than stems and leaves $\left(\eta_{P}^{2}>0.09\right)$.

Nutrient uptake. In general, 'Red Rubin' had the greatest average plant concentrations (Table 2) of all nutrients except $\mathrm{Mg}$ and $\mathrm{Mn}$ and the greatest whole plant $\mathrm{N}, \mathrm{P}$, and $\mathrm{Cu}$ contents uptake (whole plant content not shown). Plants of 'Siam Queen' had the greatest Zn uptake. 'Cinnamon' and 'Sweet Dani' had the greatest average plant $\mathrm{Mg}$ concentrations and the greatest uptake of most other nutrients. Variation among cultivars accounted for greater than $72 \%$ of variation in average plant $\mathrm{N}, \mathrm{K}, \mathrm{Mg}$, and $\mathrm{Fe}$ concentrations $\left(\eta_{C}{ }^{2}>0.72\right)$; between $50 \%$ and $68 \%$ of variation in average plant $\mathrm{S}, \mathrm{Ca}, \mathrm{B}, \mathrm{Cu}, \mathrm{Mn}$, and $\mathrm{Zn}$ concentrations; and $45 \%$ of the variation in average plant $\mathrm{P}$ concentrations. In general, variation among cultivars in nutrient uptake was smaller than variation in average plant concentrations (data not shown).

Inoculation with AMF enhanced $\mathrm{N}, \mathrm{K}, \mathrm{S}$, $\mathrm{B}, \mathrm{Fe}$, and $\mathrm{Zn}$ uptake (i.e., increased biomass, concentration, and content) (Fig. 1A). Increased $\mathrm{P}$ rate enhanced $\mathrm{P}$ and $\mathrm{Ca}$ uptake and suppressed $\mathrm{S}$ and $\mathrm{Cu}$ uptake (i.e., decreased biomass, concentration, and content) (Fig. 2A). Greater uptake (i.e., increased biomass and content but not concentration) of other nutrients in AMF-inoculated plants compared with non-inoculated plants was a result of the effects of AMF on plant biomass. Greater uptake of $\mathrm{N}, \mathrm{K}, \mathrm{B}, \mathrm{Mn}$, and $\mathrm{Zn}$ in high $\mathrm{P}$ plants compared with low $\mathrm{P}$ plants was a result of the effects of increased $P$ rate on plant biomass. In general, AMF inoculation accounted for greater proportion of variation in $\mathrm{N}\left(\eta_{A}{ }^{2}>0.34\right), \mathrm{K}\left(\eta_{A}{ }^{2}>0.22\right), \mathrm{S}\left(\eta_{A}{ }^{2}>\right.$ $0.47), \mathrm{Mg}\left(\eta_{A}{ }^{2}>0.17\right), \mathrm{B}\left(\eta_{A}{ }^{2}>0.19\right), \mathrm{Fe}\left(\eta_{A}{ }^{2}>\right.$ $0.26), \operatorname{Mn}\left(\eta_{A}^{2}>0.13\right)$, and $\mathrm{Zn}\left(\eta_{A}^{2}>0.25\right)$ uptake than $P$ rate $\left(\eta_{P}^{2}\right.$ not shown). $P$ rate accounted for a greater proportion of variation in $\mathrm{P}\left(\eta_{P}^{2}>0.59\right)$ and $\mathrm{Ca}\left(\eta_{P}^{2}>0.18\right)$ uptake than AMF inoculation ( $\eta_{A}{ }^{2}$ not shown).

Nutrient accumulation in shoots. Leaf nutrient concentrations were two to three times greater than stem concentrations (data not shown). Shoot N, P, Ca, and Zn concentrations were similar or greater than average plant concentrations (Table 2). Shoot K, S, Mg, B, Cu, $\mathrm{Fe}$, and $\mathrm{Mn}$ concentrations were less than average plant concentrations.

In general, 'Red Rubin' had the greatest shoot concentrations (Table 2) of all nutrients except $\mathrm{Mn}$ and $\mathrm{Fe}$ and accumulated the most shoot $\mathrm{N}$ and $\mathrm{S}$ (contents not shown). 'Cinnamon' had the greatest shoot Mn concentrations and shoot $\mathrm{K}, \mathrm{B}, \mathrm{Mn}$, and $\mathrm{Zn}$ content. 'Sweet Dani' had the greatest shoot Fe concentrations and shoot $\mathrm{P}, \mathrm{Ca}, \mathrm{Cu}$, and $\mathrm{Fe}$ content. 'Siam Queen' accumulated the most $\mathrm{Mg}$ in shoots. Variation among cultivars accounted for greater than $81 \%$ of variation in shoot $\mathrm{N}, \mathrm{K}$, and $\mathrm{S}$ concentrations $\left(\eta_{C}{ }^{2}>\right.$ 0.81 ); between $60 \%$ and $74 \%$ of variation in average plant $\mathrm{Ca}, \mathrm{Mg}, \mathrm{B}, \mathrm{Cu}, \mathrm{Fe}, \mathrm{Mn}$, and $\mathrm{Zn}$ concentrations; and $47 \%$ of the variation in average plant $\mathrm{P}$ concentrations. In general, variation among cultivars in shoot nutrient content was smaller than variation in shoot nutrient concentrations (data not shown).

Inoculation with $\mathrm{AMF}$ enhanced shoot accumulation of $\mathrm{N}, \mathrm{K}, \mathrm{S}, \mathrm{B}, \mathrm{Fe}$, and $\mathrm{Zn}$ (Fig. 1C). Increased $P$ rate enhanced shoot accumulation of $\mathrm{P}, \mathrm{Ca}, \mathrm{Fe}$, and $\mathrm{B}$ (Fig. 2C). Effects of $\mathrm{AMF}$ or $\mathrm{P}$ rate on shoot accumulation 
Table 2. Nutrient composition in whole plants, roots, and shoots (stems and leaves) of 16-week-old, greenhouse-grown 'Cinnamon' (CN), 'Sweet Dani' (SD), 'Siam Queen' (SQ), and 'Red Rubin' (RR) basil plants.

\begin{tabular}{|c|c|c|c|c|c|c|}
\hline \multirow[b]{2}{*}{ Nutrient by structure } & \multicolumn{4}{|c|}{ Concentrations by cultivar ${ }^{2}$} & \multicolumn{2}{|c|}{$P \leq 0.05^{\mathrm{y}}$} \\
\hline & $\mathrm{CN}$ & SD & SQ & RR & Concn & Content \\
\hline \multicolumn{7}{|l|}{ Whole plant } \\
\hline Carbon $\left(\mathrm{mg} \cdot \mathrm{g}^{-1}\right)$ & $410 b^{x}$ & $411 \mathrm{~b}$ & $410 \mathrm{~b}$ & $396 \mathrm{a}$ & $C$ & $C, A, P$ \\
\hline Nitrogen $\left(\mathrm{mg} \cdot \mathrm{g}^{-1}\right)$ & $6.44 \mathrm{a}$ & $7.18 \mathrm{a}$ & $7.11 \mathrm{a}$ & $13.78 \mathrm{~b}$ & $C, A$ & $C, A, P$ \\
\hline Phosphorus $\left(\mathrm{mg} \cdot \mathrm{g}^{-1}\right)$ & $1.21 \mathrm{a}$ & $1.40 \mathrm{~b}$ & $1.39 \mathrm{~b}$ & $1.83 \mathrm{c}$ & $C, P$ & $C, A, P, A * P$ \\
\hline Potassium $\left(\mathrm{mg} \cdot \mathrm{g}^{-1}\right)$ & $29.5 \mathrm{~b}$ & $22.5 \mathrm{a}$ & $30.5 \mathrm{~b}$ & $35.8 \mathrm{c}$ & $C, A, P$ & $C, A, P$ \\
\hline Sulfur $\left(m g \cdot g^{-1}\right)$ & $1.68 \mathrm{~b}$ & $1.38 \mathrm{a}$ & $1.81 \mathrm{~b}$ & $2.04 \mathrm{c}$ & $C, A, P$ & $C, A$ \\
\hline Calcium $\left(\mathrm{mg} \cdot \mathrm{g}^{-1}\right)$ & $9.2 \mathrm{a}$ & $10.4 \mathrm{~b}$ & $10.3 \mathrm{~b}$ & $12.2 \mathrm{c}$ & $C, P$ & $C, A, P$ \\
\hline Magnesium $\left(\mathrm{mg} \cdot \mathrm{g}^{-1}\right)$ & $36.9 \mathrm{~b}$ & $40.0 \mathrm{c}$ & $30.1 \mathrm{a}$ & $29.4 \mathrm{a}$ & $C, A, P$ & $C, A$ \\
\hline Boron $\left(\mu \mathrm{g} \cdot \mathrm{g}^{-1}\right)$ & $21.4 \mathrm{a}$ & $20.5 \mathrm{a}$ & $21.0 \mathrm{a}$ & $27.7 \mathrm{~b}$ & $C, A$ & $C, A, P$ \\
\hline Copper $\left(\mu \mathrm{g} \cdot \mathrm{g}^{-1}\right)$ & $8.2 \mathrm{a}$ & $9.4 \mathrm{a}$ & $11.7 \mathrm{~b}$ & $12.8 \mathrm{~b}$ & $C, A, P$ & $C$ \\
\hline Iron $\left(\mu \mathrm{g} \cdot \mathrm{g}^{-1}\right)$ & $866 \mathrm{a}$ & $1002 \mathrm{~b}$ & $728 \mathrm{a}$ & $1053 \mathrm{~b}$ & $C$ & $C, A$ \\
\hline Manganese $\left(\mu \mathrm{g} \cdot \mathrm{g}^{-1}\right)$ & $111 \mathrm{~b}$ & $86 \mathrm{a}$ & $100 \mathrm{ab}$ & $94 \mathrm{a}$ & $C, A, P$ & $C, A, P$ \\
\hline $\operatorname{Zinc}\left(\mu \mathrm{g} \cdot \mathrm{g}^{-1}\right)$ & $16 \mathrm{a}$ & $15 \mathrm{a}$ & $20 \mathrm{~b}$ & $21 \mathrm{~b}$ & $C, A, P$ & $C, A$ \\
\hline \multicolumn{7}{|l|}{ Shoots } \\
\hline Carbon $\left(\mathrm{mg} \cdot \mathrm{g}^{-1}\right)$ & $419 \mathrm{c}$ & $418 \mathrm{c}$ & $409 \mathrm{~b}$ & $405 \mathrm{a}$ & $C, A, P$ & $C, A, P$ \\
\hline Nitrogen $\left(\mathrm{mg} \cdot \mathrm{g}^{-1}\right)$ & $6.39 \mathrm{a}$ & $7.20 \mathrm{~b}$ & $7.28 \mathrm{~b}$ & $14.26 \mathrm{c}$ & $C, A$ & $C, A, P$ \\
\hline Phosphorus $\left(\mathrm{mg} \cdot \mathrm{g}^{-1}\right)$ & $1.26 \mathrm{a}$ & $1.47 \mathrm{~b}$ & $1.48 \mathrm{~b}$ & $1.96 \mathrm{c}$ & $C, P$ & $C, A, P$ \\
\hline Potassium $\left(\mathrm{mg}^{-\mathrm{g}^{-1}}\right)$ & $27.8 \mathrm{~b}$ & $19.7 \mathrm{a}$ & $31.0 \mathrm{c}$ & $37.3 \mathrm{~d}$ & $C, A$ & $C, A, P$ \\
\hline Sulfur $\left(\mathrm{mg} \cdot \mathrm{g}^{-1}\right)$ & $0.91 \mathrm{a}$ & $0.92 \mathrm{a}$ & $0.96 \mathrm{a}$ & $1.77 \mathrm{~b}$ & $C, A$ & $C, A, P$ \\
\hline Calcium $\left(\mathrm{mg} \cdot \mathrm{g}^{-1}\right)$ & $10.6 \mathrm{a}$ & $11.9 \mathrm{bc}$ & $12.7 \mathrm{~cd}$ & $13.9 \mathrm{~d}$ & $C$ & $C, A, P$ \\
\hline Magnesium $\left(\mathrm{mg} \cdot \mathrm{g}^{-1}\right)$ & $2.02 \mathrm{a}$ & $1.98 \mathrm{a}$ & $2.79 \mathrm{~b}$ & $3.04 \mathrm{c}$ & $C, A$ & $A, P$ \\
\hline Boron $\left(\mu \mathrm{g} \cdot \mathrm{g}^{-1}\right)$ & $16.5 \mathrm{a}$ & $16.1 \mathrm{a}$ & $19.1 \mathrm{~b}$ & $22.8 \mathrm{c}$ & $C, A$ & $C, A, P$ \\
\hline Copper $\left(\mu \mathrm{g} \cdot \mathrm{g}^{-1}\right)$ & $6.1 \mathrm{a}$ & $8.0 \mathrm{~b}$ & $8.1 \mathrm{~b}$ & $10.6 \mathrm{c}$ & $C, A$ & $C, P$ \\
\hline Iron $\left(\mu \mathrm{g} \cdot \mathrm{g}^{-1}\right)$ & $115 \mathrm{a}$ & $148 \mathrm{~b}$ & $152 \mathrm{~b}$ & $119 \mathrm{a}$ & $C, A, P$ & $C, A, P$ \\
\hline Manganese $\left(\mu \mathrm{g} \cdot \mathrm{g}^{-1}\right)$ & $107 \mathrm{~b}$ & $85 \mathrm{a}$ & $103 \mathrm{~b}$ & $91 \mathrm{a}$ & $C, A, P$ & $C, A, P$ \\
\hline $\operatorname{Zinc}\left(\mu \mathrm{g} \cdot \mathrm{g}^{-1}\right)$ & $16 \mathrm{a}$ & $15 \mathrm{a}$ & $22 \mathrm{~b}$ & $21 \mathrm{~b}$ & $C, A, P$ & $C, A, P$ \\
\hline \multicolumn{7}{|l|}{ Roots } \\
\hline Carbon $\left(\mathrm{mg} \cdot \mathrm{g}^{-1}\right)$ & $377 \mathrm{a}$ & $374 \mathrm{ab}$ & $413 \mathrm{~b}$ & $359 \mathrm{a}$ & $C$ & $C, A, P$ \\
\hline Nitrogen $\left(\mathrm{mg} \cdot \mathrm{g}^{-1}\right)$ & $6.60 \mathrm{a}$ & $7.13 \mathrm{a}$ & $6.63 \mathrm{a}$ & $11.58 \mathrm{~b}$ & $C, A$ & $C, A$ \\
\hline Phosphorus $\left(\mathrm{mg} \cdot \mathrm{g}^{-1}\right)$ & $1.03 \mathrm{a}$ & $1.08 \mathrm{ab}$ & $1.10 \mathrm{ab}$ & $1.23 \mathrm{~b}$ & $C, P$ & $C, A, P$ \\
\hline Potassium $\left(\mathrm{mg} \cdot \mathrm{g}^{-1}\right)$ & $35.2 \mathrm{~b}$ & $33.9 \mathrm{~b}$ & $28.9 \mathrm{a}$ & $29.1 \mathrm{a}$ & $C, A$ & $C, A, P$ \\
\hline Sulfur $\left(\mathrm{mg} \cdot \mathrm{g}^{-1}\right)$ & $4.26 \mathrm{~b}$ & $3.19 \mathrm{a}$ & $4.25 \mathrm{~b}$ & $3.30 \mathrm{a}$ & $C, A, P$ & $C, A, P$ \\
\hline Calcium $\left(\mathrm{mg} \cdot \mathrm{g}^{-1}\right)$ & $4.42 \mathrm{~b}$ & $4.41 \mathrm{~b}$ & $3.59 \mathrm{a}$ & $4.49 \mathrm{~b}$ & $C, A$ & $C, A$ \\
\hline Magnesium $\left(\mathrm{mg} \cdot \mathrm{g}^{-1}\right)$ & $160 \mathrm{bc}$ & $198 \mathrm{c}$ & $108 \mathrm{a}$ & $145 \mathrm{ab}$ & $C, A$ & $C, A$ \\
\hline Boron $\left(\mu \mathrm{g} \cdot \mathrm{g}^{-1}\right)$ & $39.1 \mathrm{ab}$ & $38.8 \mathrm{ab}$ & $26.4 \mathrm{a}$ & $49.2 \mathrm{~b}$ & $C, A$ & $C, A, P$ \\
\hline Copper $\left(\mu \mathrm{g} \cdot \mathrm{g}^{-1}\right)$ & $15.2 \mathrm{a}$ & $14.8 \mathrm{a}$ & $21.9 \mathrm{~b}$ & $22.3 \mathrm{~b}$ & $C, P$ & $C, P$ \\
\hline Iron $\left(\mathrm{mg} \cdot \mathrm{g}^{-1}\right)$ & $3.55 \mathrm{~b}$ & $4.51 \mathrm{bc}$ & $2.35 \mathrm{a}$ & $5.17 \mathrm{c}$ & $C, A, P$ & $C, A$ \\
\hline Manganese $\left(\mu \mathrm{g} \cdot \mathrm{g}^{-1}\right)$ & $128 \mathrm{~b}$ & $89 \mathrm{a}$ & $94 \mathrm{a}$ & $108 \mathrm{a}$ & $C, A, P$ & $C, A, P$ \\
\hline Zinc $\left(\mu \mathrm{g} \cdot \mathrm{g}^{-1}\right)$ & $17.4 \mathrm{a}$ & $16.9 \mathrm{a}$ & $15.2 \mathrm{a}$ & $20.7 \mathrm{~b}$ & $C, A$ & $C, A$ \\
\hline
\end{tabular}

${ }^{2}$ Concentrations based on oven-dried biomass.

yPlants were grown with a complete fertilizer containing $16 \mathrm{mg} \cdot \mathrm{L}^{-1}(\mathrm{LP})$ or $32 \mathrm{mg} \cdot \mathrm{L}^{-1}(\mathrm{HP})$ phosphorus $(\mathrm{P})$ fertilizer and inoculated (AMF) or not (non-AMF) with the arbuscular mycorrhizal fungus, Rhizophagus intraradices. Significant $(P \leq 0.05)$ effects of concentration or content data for cultivar $(C)$, AMF treatment $(\mathrm{A}), \mathrm{P}$ rate $(\mathrm{P})$, and their interactions (e.g., $\mathrm{A} * \mathrm{P})$.

${ }^{x}$ Means within a row followed by the same lower case letter are not significantly different at $P \leq 0.05$ using Tukey's honestly significant difference $(\mathrm{n}=20)$.

of other nutrients were a result of the effects of $\mathrm{AMF}$ and $\mathrm{P}$ rate on biomass. In general, AMF inoculation accounted for a greater proportion of variation in shoot $\mathrm{N}\left(\eta_{A}{ }^{2}>0.27\right), \mathrm{K}\left(\eta_{A}{ }^{2}>\right.$ $0.18), \mathrm{S}\left(\eta_{A}^{2}>0.23\right), \mathrm{B}\left(\eta_{A}^{2}>0.38\right), \mathrm{Fe}\left(\eta_{A}{ }^{2}>\right.$ $0.27)$, and $\mathrm{Zn}\left(\eta_{A}{ }^{2}>0.19\right)$ content than $\mathrm{P}$ rate $\left(\eta_{P}^{2}\right.$ not shown). $P$ rate accounted for a greater proportion of variation in shoot $\mathrm{P}\left(\eta_{P}^{2}>0.64\right)$, $\mathrm{Ca}\left(\eta_{P}^{2}>0.23\right), \mathrm{Mg}\left(\eta_{P}^{2}>0.28\right), \mathrm{Cu}\left(\eta_{P}^{2}>\right.$ $0.11)$, and $\mathrm{Mn}\left(\eta_{P}^{2}>0.7\right)$ content than AMF inoculation ( $\eta_{A}{ }^{2}$ not shown).

Nutrient accumulation in roots. Root $\mathrm{S}$, $\mathrm{Mg}, \mathrm{B}, \mathrm{Cu}$, and $\mathrm{Fe}$ concentrations (Table 2) were greater than leaf concentrations (data not shown). Root $\mathrm{K}, \mathrm{S}, \mathrm{Mg}, \mathrm{B}, \mathrm{Cu}, \mathrm{Fe}$, and $\mathrm{Mn}$ concentrations were similar or greater than average plant concentrations (Table 2). Root $\mathrm{N}, \mathrm{P}$, and $\mathrm{Ca}$ were less than average plant concentrations.

In general, 'Red Rubin' had the greatest root $\mathrm{N}, \mathrm{P}, \mathrm{Cu}, \mathrm{Fe}$, and $\mathrm{Zn}$ concentrations (Table 2) and accumulated the least root biomass. In general, AMF inoculation accounted for a greater proportion of variation in root $\mathrm{N}\left(\eta_{A}{ }^{2}>0.53\right), \mathrm{P}\left(\eta_{A}{ }^{2}>0.14\right)$, $\mathrm{K}\left(\eta_{A}{ }^{2}>0.10\right), \mathrm{S}\left(\eta_{A}{ }^{2}>0.25\right), \mathrm{Ca}\left(\eta_{A}{ }^{2}>0.16\right)$, $\operatorname{Mg}\left(\eta_{A}{ }^{2}>0.17\right), \mathrm{B}\left(\eta_{A}{ }^{2}>0.13\right), \mathrm{Fe}\left(\eta_{A}{ }^{2}>\right.$ $0.15)$, and $\mathrm{Zn}\left(\eta_{A}^{2}>0.07\right)$ content than $\mathrm{P}$ rate $\left(\eta_{P}^{2}\right.$ not shown). P rate accounted for a greater proportion of variation in $\operatorname{root} \mathrm{Cu}$ $\left(\eta_{P}^{2}>0.15\right)$ content than AMF inoculation ( $\eta_{A}^{2}$ not shown).

Phenolic production. In general, 'Red Rubin' had the greatest average plant ACY and P2-P4 concentrations (Table 3) and the greatest whole plant $\mathrm{ACY}$ and $\mathrm{P} 4$ content production (content data not shown). 'Cinnamon' had the greatest average plant concentrations and production of $\mathrm{P} 6$ and $\mathrm{P} 8$; 'Sweet Dani' had the greatest average plant concentrations of P5 and P7 and production of P3, P5, and P7; and 'Siam Queen' had the greatest average plant concentrations of $\mathrm{TP}$, P9-P11, and MPP and production of P10 and $\mathrm{P} 11$. Variation among cultivars accounted for greater than $90 \%$ of variation in average plant P10 concentrations $\left(\eta_{C}^{2}>0.90\right)$; between $61 \%$ and $79 \%$ of variation in average plant TP, P7, and P11 concentrations; and 49\% to $60 \%$ of the variation in average plant concentrations of other measured phenolics. In general, variation among cultivars in TP, P2, P3, $\mathrm{P} 6, \mathrm{P} 8$, and $\mathrm{P} 11$ production was generally greater than variation among cultivars in average plant concentrations and variation among cultivars in $\mathrm{P} 5, \mathrm{P} 7, \mathrm{P} 9$, and $\mathrm{P} 10$ production was smaller than variation among cultivars in average plant concentrations (data not shown).

Inoculation with AMF increased $\mathrm{ACY}$ ('Red Rubin' only; data not shown), P2, P4-P7, and MPP production (Fig. 1B). Increased P rate enhanced ACY ('Red Rubin' only; data not shown), P3, P6-P9, and MPP production and suppressed $\mathrm{P} 5$ production (Fig. 2B). Significant effects of AMF or P rate on production of other phenolics was a result of the effects of AMF and $P$ rate on plant biomass. In general, AMF inoculation accounted for a greater proportion of variation in $\mathrm{P} 4$ $\left(\eta_{A}{ }^{2}>0.13\right), \mathrm{P} 5\left(\eta_{A}{ }^{2}>0.17\right), \mathrm{P} 7\left(\eta_{A}{ }^{2}>0.12\right)$, and MPP $\left(\eta_{A}{ }^{2}>0.16\right)$ production than $\mathrm{P}$ rate $\left(\eta_{P}^{2}\right.$ not shown). P rate accounted for a greater proportion of variation in P3 $\left(\eta_{P}^{2}>0.22\right)$ and P8 $\left(\eta_{P}{ }^{2}>0.18\right)$ than AMF inoculation $\left(\eta_{A}{ }^{2}\right.$ not shown).

Phenolic accumulation in shoots. Specific phenolics were only detected in shoots (e.g., P2, P3, and P6-P9; Table 3). Leaf phenolic concentrations were two to six times greater than stem concentrations (data not shown). Shoot TP, P4, P8-P10, and MPP concentrations were similar or greater than average plant concentrations (Table 3). Shoot P5 and P11 concentrations were less than average plant concentrations.

In general, 'Red Rubin' had the greatest shoot concentrations (Table 3) of ACY, P2, and $\mathrm{P} 4$ and accumulated the most shoot ACY, $\mathrm{P} 2$, and $\mathrm{P} 4$ content (content data not shown). 'Cinnamon' had the greatest shoot concentrations of P6 and P7 and shoot P6-P9 content. 'Sweet Dani' had the greatest shoot P7 

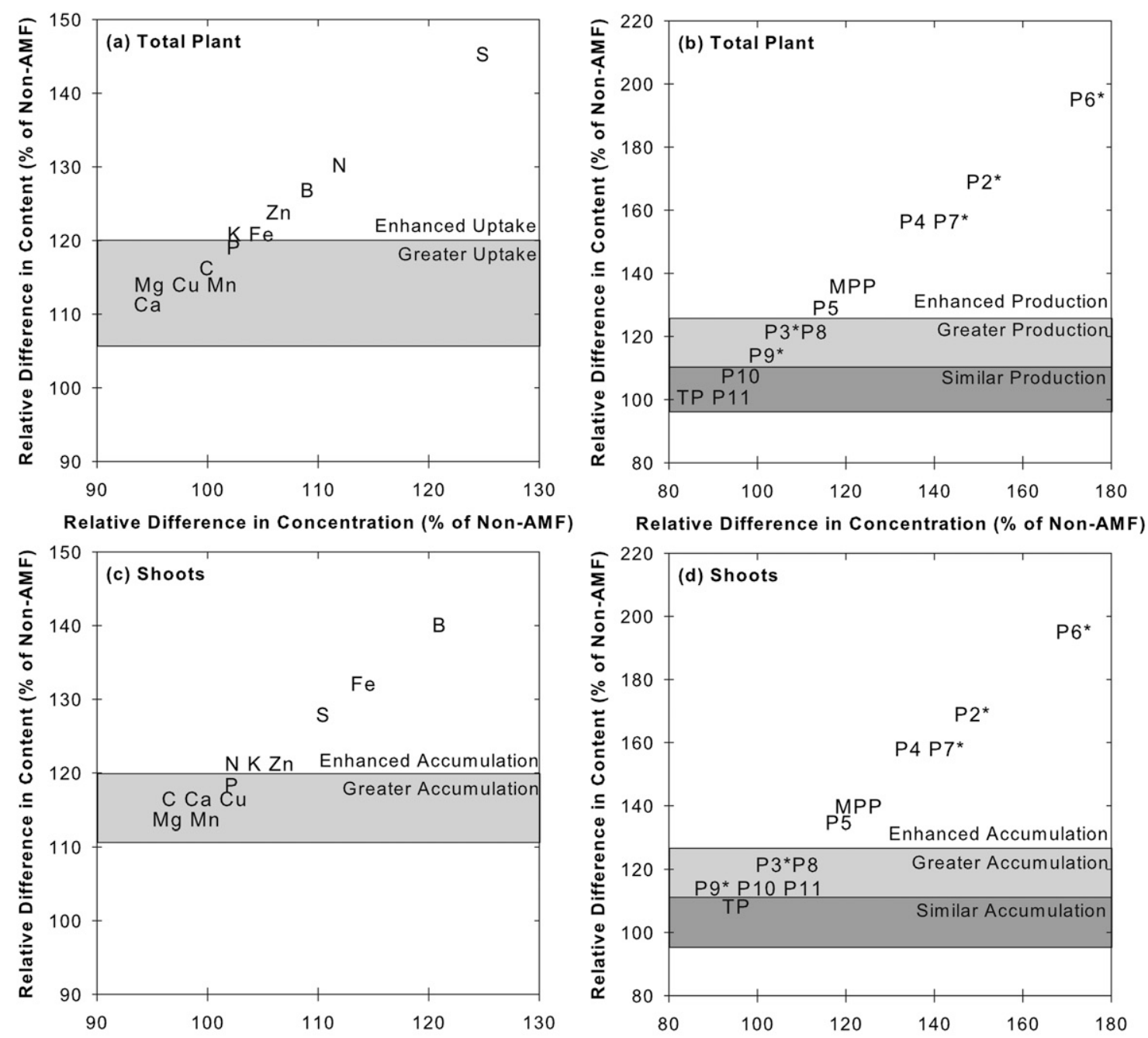

Relative Difference in Concentration (\% of Non-AMF)

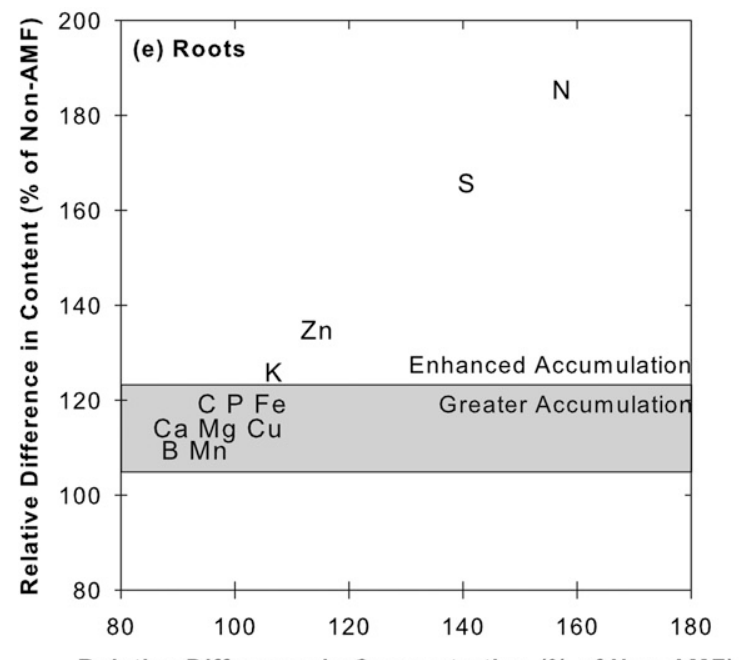

Relative Difference in Concentration (\% of Non-AMF)

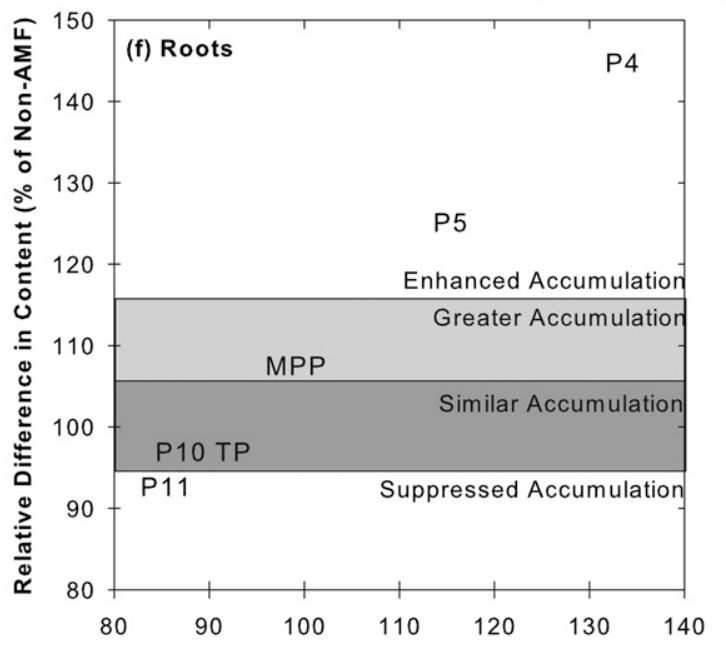

Relative Difference in Concentration (\% of Non-AMF)

Fig. 1. Relative differences in concentration and content of nutrients and phenolics in (a-b) whole plants, (c-d) shoots (stems and leaves), and (e-f) roots of 16-week-old, greenhouse-grown, basil plants inoculated or not (non-AMF) with the AMF, Rhizophagus intraradices. Shaded bars distinguish the following: enhanced (greater biomass, concentration, and content); greater (greater biomass, similar concentration, greater content); similar (greater biomass, lower concentration, and similar content); suppressed (greater biomass, lower concentration, and lower content). Significant differences in biomass, concentration, and content determined by analysis of variance (ANOVA) or Kruskal-Wallis ANOVA and median test at $P \leq 0.05$ (nutrients, $\mathrm{n}=$ 40; phenolics, $\mathrm{n}=24)$. Asterisk (*) denotes compounds detected only in shoots. Polyphenolic peak designation (P2-P11) as described in Lee and Scagel (2009, 2010). MPP = sum of P2-P8 and P10. Definitions for phenolic acronyms given in Table 3. AMF = arbuscular mycorrhizal fungus; MPP = minor polyphenolics. 

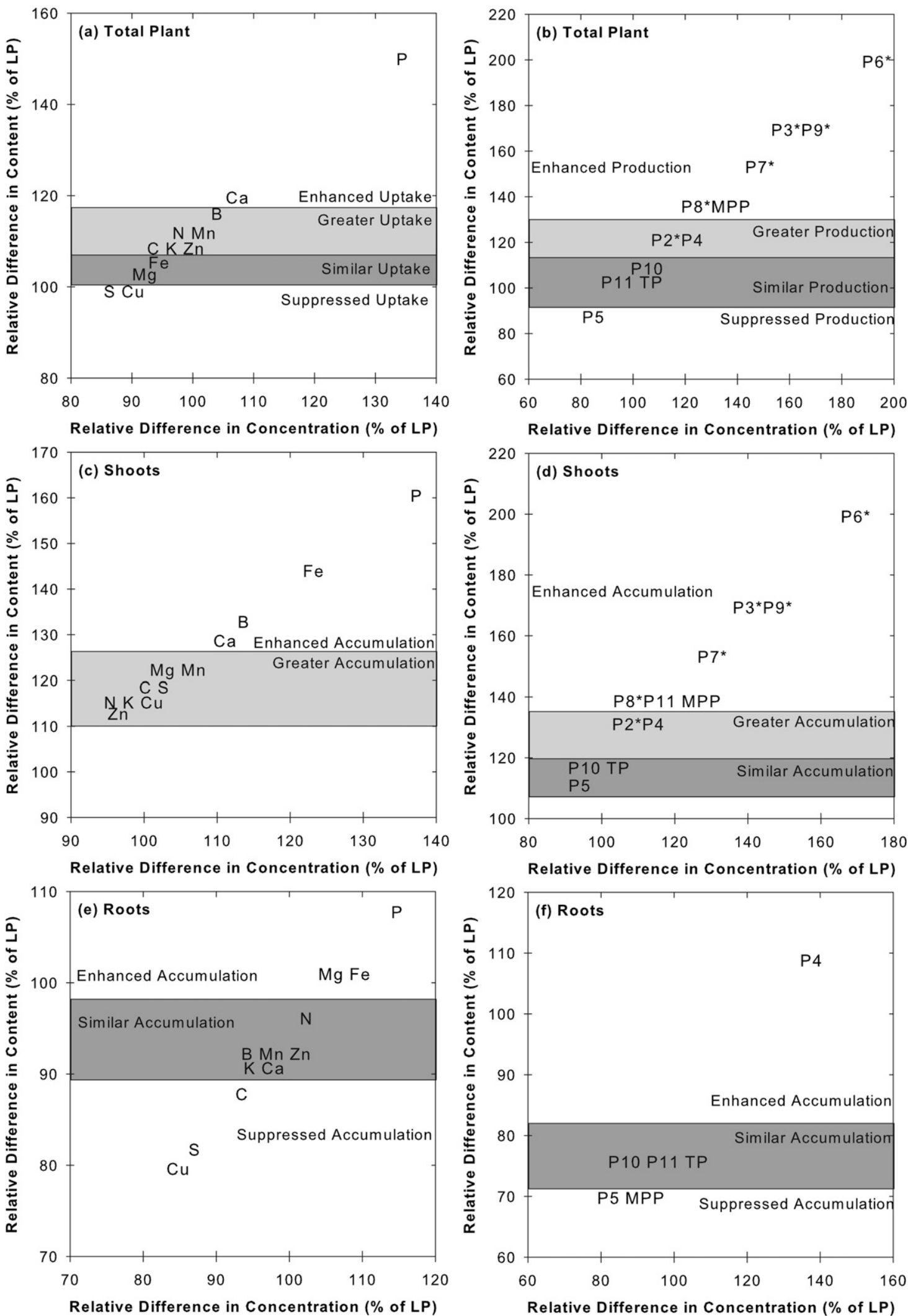

Fig. 2. Relative differences in concentration and content of nutrients and phenolics in (a-b) whole plants, (c-d) shoots (stems and leaves), and (e-f) roots of 16week-old, greenhouse-grown basil plants grown with a complete fertilizer containing $16 \mathrm{mg} \cdot \mathrm{L}^{-1}(\mathrm{LP}) \mathrm{or} 32 \mathrm{mg} \cdot \mathrm{L}^{-1}(\mathrm{HP}) \mathrm{P}$. Shaded bars distinguish the following: enhanced (greater biomass, concentration, and content); greater (greater biomass, similar concentration, greater content); similar (greater biomass, lower concentration, and similar content); suppressed (greater biomass, lower concentration, and lower content). Significant differences in biomass, concentration, and content determined by analysis of variance (ANOVA) or Kruskal-Wallis ANOVA and median test at $P \leq 0.05$ (nutrients, $\mathrm{n}=40$; $\mathrm{phenolics,}$ $\mathrm{n}=24)$. Asterisk (*) denotes compounds detected only in shoots. Polyphenolic peak designation $(\mathrm{P} 2-\mathrm{P} 11)$ as described in Lee and Scagel $(2009$, 2010). MPP = sum of P2-P8 and P10. Definitions for phenolic acronyms given in Table 3. LP = low phosphorus; HP = high phosphorus; MPP $=$ minor polyphenolics. 
Table 3. Phenolic composition in whole plants and shoots (stems and leaves) of 16-week-old, greenhousegrown 'Cinnamon' (CN), 'Sweet Dani' (SD), 'Siam Queen' (SQ), and 'Red Rubin' (RR) basil plants.

\begin{tabular}{|c|c|c|c|c|c|c|}
\hline \multirow[b]{2}{*}{ Phenolic by structure } & \multicolumn{4}{|c|}{ Concentrations by cultivar ${ }^{2}$} & \multicolumn{2}{|c|}{$P \leq 0.05^{y}$} \\
\hline & $\mathrm{CN}$ & SD & SQ & RR & Concn & Conten \\
\hline \multicolumn{7}{|l|}{ Whole plant } \\
\hline Anthocyanins (ACY) $\left(\mathrm{mg} \cdot \mathrm{g}^{-1}\right)$ & $0.02 \mathrm{a}^{\mathrm{x}}$ & ND & $0.05 \mathrm{a}$ & $0.84 \mathrm{~b}$ & - & - \\
\hline Total phenolics (TP) $\left(\mathrm{mg}^{-1} \mathrm{~g}^{-1}\right)$ & $7.13 \mathrm{~b}$ & $5.66 \mathrm{a}$ & $8.07 \mathrm{c}$ & $5.94 \mathrm{a}$ & $C$ & $C$ \\
\hline Feruloyl tartaric acid (P4) $\left(\mu \mathrm{g} \cdot \mathrm{g}^{-1}\right)$ & $3.4 \mathrm{a}$ & $2.7 \mathrm{a}$ & $2.8 \mathrm{a}$ & $8.7 \mathrm{~b}$ & $C, A$ & $C, A, P$ \\
\hline Caffeic acid (P5) $\left(\mu \mathrm{g} \cdot \mathrm{g}^{-1}\right)$ & $8.9 \mathrm{a}$ & $13.5 \mathrm{~b}$ & $8.4 \mathrm{a}$ & $7.2 \mathrm{a}$ & $C, A$ & $C, A, P$ \\
\hline Cinnamic acid derivative $(\mathrm{P} 10)\left(\mu \mathrm{g} \cdot \mathrm{g}^{-1}\right)$ & $17.0 \mathrm{a}$ & $17.2 \mathrm{a}$ & $68.3 \mathrm{c}$ & $29.0 \mathrm{~b}$ & $C$ & $C$ \\
\hline Rosmarinic acid (P11) $\left(\mathrm{mg} \cdot \mathrm{g}^{-1}\right)$ & $1.60 \mathrm{~b}$ & $1.39 \mathrm{~b}$ & $2.04 \mathrm{c}$ & $1.07 \mathrm{a}$ & $C$ & $C$ \\
\hline Minor polyphenolics $\left(\mu \mathrm{g} \cdot \mathrm{g}^{-1}\right)$ & $92 \mathrm{a}$ & $103 \mathrm{ab}$ & $117 \mathrm{~b}$ & $99 \mathrm{a}$ & $C, A, P$ & $C, A, P$ \\
\hline \multicolumn{7}{|l|}{ Shoots } \\
\hline Antho & $0.04 \mathrm{a}$ & ND & $0.07 \mathrm{a}$ & $1.07 \mathrm{~b}$ & - & - \\
\hline Tot: & $7.26 \mathrm{~b}$ & $5.67 \mathrm{a}$ & $8.51 \mathrm{c}$ & $5.74 \mathrm{a}$ & $C$ & $C, A, P$ \\
\hline d (P2) ( & $3.9 \mathrm{c}$ & $1.5 \mathrm{a}$ & $2.2 \mathrm{~b}$ & $6.2 \mathrm{~d}$ & $C, A$ & $C, A, P$ \\
\hline lic acid (P3) $\left(\mu \mathrm{g} \cdot \mathrm{g}^{-1}\right)$ & $1.1 \mathrm{ab}$ & $1.5 \mathrm{bc}$ & $0.9 \mathrm{a}$ & $1.6 \mathrm{c}$ & $C, P$ & $C, A, P$ \\
\hline $\mathrm{d}(\mathrm{P} 4)\left(\mu \mathrm{g} \cdot \mathrm{g}^{-1}\right)$ & $4.2 \mathrm{a}$ & $3.4 \mathrm{a}$ & $3.5 \mathrm{a}$ & $10.9 \mathrm{~b}$ & $C, A$ & $C, A, P$ \\
\hline $\mathrm{Caf}$ & $6.2 \mathrm{~b}$ & $7.1 \mathrm{~b}$ & $6.9 \mathrm{~b}$ & $4.6 \mathrm{a}$ & $C, A$ & $C, A$ \\
\hline$* \mathrm{Ca}$ & $5.7 \mathrm{c}$ & $2.8 \mathrm{a}$ & $3.1 \mathrm{ab}$ & $4.5 \mathrm{bc}$ & $C, A, P$ & $C, A, P$ \\
\hline *Chic & $74.6 \mathrm{~b}$ & $96.8 \mathrm{c}$ & $49.4 \mathrm{a}$ & $50.8 \mathrm{a}$ & $C, A, P$ & $C, A, P$ \\
\hline (P8) $\left(\mu \mathrm{g} \cdot \mathrm{g}^{-1}\right)$ & $10.6 \mathrm{c}$ & $7.1 \mathrm{~b}$ & $2.5 \mathrm{a}$ & $6.7 \mathrm{~b}$ & $C, P$ & $C, A, P$ \\
\hline (P9) $\left(\mu \mathrm{g} \cdot \mathrm{g}^{-1}\right)$ & $123 \mathrm{~b}$ & $25 \mathrm{a}$ & $154 \mathrm{c}$ & $26 \mathrm{a}$ & $C, P$ & $C, P$ \\
\hline Cinn & $18.0 \mathrm{a}$ & $19.4 \mathrm{a}$ & $98.8 \mathrm{c}$ & $33.2 \mathrm{~b}$ & C & $C$ \\
\hline & $138 \mathrm{~b}$ & $1.21 \mathrm{~b}$ & $2.13 \mathrm{c}$ & $0.84 \mathrm{a}$ & $C$ & $C, A, P$ \\
\hline Minor polyphenolics (MPI & $124 \mathrm{a}$ & $140 \mathrm{~b}$ & $167 \mathrm{c}$ & $118 \mathrm{a}$ & $C, A, P$ & $C, A, P$ \\
\hline \multicolumn{7}{|l|}{ Roots } \\
\hline Anthocy & ND & ND & ND & 0.03 & - & 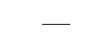 \\
\hline Total $\mathrm{p}$ & $6.81 \mathrm{~b}$ & $5.60 \mathrm{a}$ & $7.35 \mathrm{c}$ & $6.65 \mathrm{~b}$ & $C$ & $C, P$ \\
\hline 4) $\left(\mu g \cdot g^{-1}\right)$ & $1.80 \mathrm{a}$ & $1.15 \mathrm{a}$ & $1.14 \mathrm{a}$ & $1.10 \mathrm{a}$ & NS & $C, A$ \\
\hline Caffei & $1.37 \mathrm{ab}$ & $2.44 \mathrm{c}$ & $1.08 \mathrm{a}$ & $1.66 \mathrm{~b}$ & $C, A, P$ & $C, A, P$ \\
\hline id deriva & $14.4 \mathrm{a}$ & $13.2 \mathrm{a}$ & $14.0 \mathrm{a}$ & $15.5 \mathrm{a}$ & NS & $C, P$ \\
\hline Rosmarinic acid (P11) $\left(\mathrm{mg} \cdot \mathrm{g}^{-1}\right)$ & $1.92 \mathrm{a}$ & $1.69 \mathrm{a}$ & $1.91 \mathrm{a}$ & $1.87 \mathrm{a}$ & NS & $C, P$ \\
\hline Minor polyphenolics $\left(\mu \mathrm{g} \cdot \mathrm{g}^{-1}\right)$ & $29.9 \mathrm{ab}$ & $39.1 \mathrm{c}$ & $26.0 \mathrm{a}$ & $33.2 \mathrm{~b}$ & $C$ & $C, A, P$ \\
\hline
\end{tabular}

${ }^{\mathrm{z}}$ Concentrations based on fresh biomass. Polyphenolic peak designation (P2-P11) as described in Lee and Scagel $(2009,2010)$. MPP = sum of P2-P8 and P10. Units: ACY (cyanidin-glucoside); TP (gallic acid); P9 (quercetin-rutinoside); and all others (caffeic acid). Compounds proceeded by an asterisk (*) only detected in shoots (stems and leaves). ND = not detected.

${ }^{y}$ Plants were grown with a complete fertilizer containing $16 \mathrm{mg} \cdot \mathrm{L}^{-1}(\mathrm{LP})$ or $32 \mathrm{mg} \cdot \mathrm{L}^{-1}(\mathrm{HP})$ phosphorus $(\mathrm{P})$ phosphorus (P) fertilizer and inoculated (AMF) or not (non-AMF) with the arbuscular mycorrhizal fungus, Rhizophagus intraradices. Significant $(P \leq 0.05)$ effects of concentration or content data for cultivar $(C)$, AMF treatment $(\mathrm{A}), \mathrm{P}$ rate $(\mathrm{P})$. Non-significant main effects denoted by ns. There were no significant interactions between main effects.

${ }^{x}$ Means within a row followed by the same lower case letter are not significantly different at $P<0.05$ using Tukey's honestly significant difference or Kruskal-Wallis analysis of variance $(\mathrm{n}=12)$.

concentration and shoot P3, P5, P7, and MPP content. 'Siam Queen' had the greatest shoot TP, P9-P11, and MPP concentrations and shoot TP, P10, and P11 content. Variation among cultivars accounted for greater than $72 \%$ of variation in shoot TP, P10, and P11 concentrations $\left(\eta_{C}^{2}>0.72\right)$; between $49 \%$ and $61 \%$ of variation in shoot P2-P9 concentrations; and $35 \%$ of variation in shoot MPP concentrations. Variation among cultivars in shoot TP, P7, and P9-P11 content was generally smaller than variation in shoot concentrations and variation among cultivars in shoot P2-P3, P5, P6, P8, and MPP content was generally greater than variation in shoot concentrations (data not shown).

Inoculation with AMF enhanced shoot accumulation of ACY ('Red Rubin' only; data not shown), P2, P4-P7, and MPP (Fig. 1D). Increased $P$ rate enhanced shoot accumulation of ACY ('Red Rubin' only; data not shown), P3, P6-P9, and MPP (Fig. 2D). Significant effects of AMF or $\mathrm{P}$ rate on shoot accumulation of other phenolics were a result of the effects of AMF and $\mathrm{P}$ rate on biomass. In general, AMF inoculation accounted for a greater proportion of variation in shoot $\mathrm{P} 4$ $\left(\eta_{A}{ }^{2}>0.11\right)$, P5 $\left(\eta_{A}{ }^{2}>0.09\right)$, P7 $\left(\eta_{A}{ }^{2}>0.12\right)$, and MPP $\left(\eta_{A}{ }^{2}>0.21\right)$ content than $\mathrm{P}$ rate $\left(\eta_{P}{ }^{2}\right.$ not shown). $\mathrm{P}$ rate accounted for a greater proportion of variation in shoot TP $\left(\eta_{P}^{2}>\right.$ $0.15), \mathrm{P} 3\left(\eta_{P}^{2}>0.22\right), \mathrm{P} 8\left(\eta_{P}^{2}>0.18\right), \mathrm{P} 9\left(\eta_{P}^{2}>\right.$ $0.09)$, and P11 $\left(\eta_{P}^{2}>0.11\right)$ content than AMF inoculation ( $\eta_{A}^{2}$ not shown).

Phenolic accumulation in roots. Root TP, $\mathrm{P} 5$, and P10 concentrations (Table 3) were greater than leaf concentrations (data not shown). Root P5 and P11 were similar or greater than average plant concentrations (Table 3). Root TP, P4, P8-P10, and MPP concentrations were less than average plant concentrations. Only 'Red Rubin' roots contained detectable amounts of ACY.

In general, 'Sweet Dani' had the greatest root concentrations (Table 3) and P5 and MPP content (data not shown). 'Cinnamon' had the greatest P4, P10, P11, and TP content. Variation among cultivars accounted for greater than $24 \%$ of variation in root TP, P5, and MPP $\left(\eta_{C}^{2}>0.24\right)$. Variation among cultivars in root phenolic content was generally greater than variation in root phenolic concentrations (data not shown).

Inoculation with AMF enhanced root accumulation of P4 and P5 in roots and suppressed root accumulation of P11 (Fig. 1F).
Increased $\mathrm{P}$ rate enhanced root accumulation of $\mathrm{P} 4$ and suppressed root accumulation of P5 and MPP (Fig. 2F). Significant effects of AMF on root accumulation of other phenolics were a result of the effects of AMF on biomass. In general, AMF inoculation accounted for a greater proportion of variation in root $\mathrm{P} 4$ $\left(\eta_{A}{ }^{2}>0.17\right)$ content than $\mathrm{P}$ rate $\left(\eta_{P}{ }^{2}\right.$ not shown). $\mathrm{P}$ rate accounted for a greater proportion of variation in root TP $\left(\eta_{P}^{2}>0.13\right)$, P5 $\left(\eta_{P}^{2}>0.17\right)$, P10 $\left(\eta_{P}^{2}>0.07\right)$, P11 $\left(\eta_{P}^{2}>\right.$ $0.10)$, and MPP $\left(\eta_{P}^{2}>0.12\right)$ content than AMF inoculation ( $\eta_{A}{ }^{2}$ not shown).

Relationships between nutrient uptake and phenolics. Inoculation with AMF enhanced P2, P4-P7, and MPP production and N, K, S, $\mathrm{B}, \mathrm{Fe}$, and $\mathrm{Zn}$ uptake (Fig. 1A-B). Enhanced $\mathrm{P} 2$ and $\mathrm{P} 6$ production in AMF-inoculated plants was related to enhanced $\mathrm{N}$ uptake; enhanced $\mathrm{P} 4$ production was related to enhanced $\mathrm{N}$ and $\mathrm{Fe}$ uptake; enhanced $\mathrm{P} 5$ production was related to enhanced $\mathrm{S}, \mathrm{B}$, and $\mathrm{Fe}$ uptake; enhanced P7 and MPP production was related to enhanced K, B, and Fe uptake (Table 4). Increased $\mathrm{P}$ rate enhanced $\mathrm{P}$ 3, $\mathrm{P} 6-\mathrm{P} 9$, and MPP production and $\mathrm{P}$ and $\mathrm{Ca}$ uptake (Fig. 2A-B). Enhanced P3 and P6 production was related to enhanced P uptake; enhanced P7, P8, and MPP production was related to enhanced $\mathrm{P}$ and $\mathrm{Ca}$ uptake (Table 4). Enhanced P9 production in HP plants was not correlated to P-enhanced uptake of any nutrient measured.

Inoculation with AMF enhanced accumulation of P4 and P5 in shoots and roots and MPP in shoots (Figs. 1D and 1F). AMFenhanced $\mathrm{P} 4$ accumulation in shoots was related to enhanced $\mathrm{N}$ and $\mathrm{Fe}$ uptake and enhanced $\mathrm{P} 4$ accumulation in roots was related to enhanced Fe uptake (Table 4). AMFenhanced P5 accumulation in shoots was related to enhanced $\mathrm{S}, \mathrm{B}$, and Fe uptake and enhanced P5 accumulation in roots was related to enhanced $\mathrm{S}$ and $\mathrm{B}$ uptake. AMFenhanced MPP accumulation in roots was related to enhanced $\mathrm{B}$ and $\mathrm{Fe}$ uptake. Increased $P$ rate enhanced accumulation of $\mathrm{P} 11$ and MPP in shoots and P4 in roots (Figs. 2D and $2 \mathrm{~F}$ ). Enhanced MPP accumulation in shoots of HP plants was related to enhanced $\mathrm{P}$ and $\mathrm{Ca}$ uptake (Table 4). Enhanced P11 accumulation in shoots and $\mathrm{P} 4$ accumulation in roots of HP plants were related to enhanced Ca uptake.

\section{Discussion}

Root colonization. Root colonization by AMF in our study was $10 \%$ to $30 \%$ higher than that reported for other basil cultivars (e.g., 'Genovese', 'Purple Petra') inoculated with the same isolate of AMF or with different species [e.g., Funneliformis (formerly Glomus) mosseae (Nicolson \& Gerd.) Walker \& Schüßler, Gigaspora rosea Nicolson \& Schenck, Gi. margarita Becker \& Hall] (Copetta et al., 2006; Lee and Scagel, 2009; Toussaint et al., 2007). Methods used to quantify AMF can yield different results, particularly when quantifying colonization of different AMF species (McGonigle et al., 2006), and AMF colonization can increase over time 
Table 4. Relationships between nutrient uptake and phenolic production of 16-week-old, greenhousegrown basil plants.

\begin{tabular}{|c|c|c|c|}
\hline \multirow[b]{3}{*}{ Variable $^{\mathrm{z}}$} & \multicolumn{3}{|c|}{ Significant correlations $^{\mathrm{y}}$} \\
\hline & \multicolumn{3}{|c|}{ Whole plant nutrient uptake vs. } \\
\hline & Whole plant production & Shoot accumulation & Root accumulation \\
\hline Total phenolics (TP) & $\mathrm{K}, \mathrm{S}, \mathrm{Mg}, \mathrm{B}, \mathrm{Mn}, \mathrm{Zn}$ & $\mathrm{K}, \mathrm{S}, \mathrm{Mn}, \mathrm{Zn}$ & $\mathrm{Mg}, \mathrm{B}$ \\
\hline *Caftaric acid (P2) & $\mathrm{N}$ & $\mathrm{N}$ & - \\
\hline${ }^{*}$ Cinnamyl ma & $\mathrm{N}, \mathrm{P}$ & $\mathrm{N}, \mathrm{P}$ & - \\
\hline $\operatorname{acid}(\mathrm{P} 4)$ & $\mathrm{N}, \mathrm{Mg}, \mathrm{Fe}$ & $\mathrm{N}, \mathrm{Fe}$ & $\mathrm{Ca}, \mathrm{Fe}, \mathrm{Mg}$ \\
\hline Caffeic acid (P5) & $\mathrm{S}, \mathrm{Ca}, \mathrm{Mg}, \mathrm{B}, \mathrm{Cu}, \mathrm{Fe}, \mathrm{Mn}$ & $\mathrm{S}, \mathrm{Ca}, \mathrm{Mg}, \mathrm{B}, \mathrm{Cu}, \mathrm{Mn}$ & $\mathrm{S}, \mathrm{Ca}, \mathrm{Mg}, \mathrm{B}, \mathrm{Cu}$ \\
\hline${ }^{*}$ Caffeic acid derivative (P6) & $\mathrm{N}, \mathrm{P}$ & $\mathrm{N}, \mathrm{P}$ & - \\
\hline *Chicoric a & $\mathrm{P}, \mathrm{Ca}, \mathrm{Mg}, \mathrm{B}, \mathrm{Fe}, \mathrm{Mn}$ & $\mathrm{P}, \mathrm{Ca}, \mathrm{Mg}, \mathrm{B}, \mathrm{Fe}, \mathrm{Mn}$ & - \\
\hline tive (P8) & $\mathrm{P}, \mathrm{K}, \mathrm{Ca}, \mathrm{B}, \mathrm{Fe}, \mathrm{Mn}$ & $\mathrm{P}, \mathrm{K}, \mathrm{Ca}, \mathrm{B}, \mathrm{Fe}, \mathrm{Mn}$ & - \\
\hline *Quercetin-ru & $\mathrm{K}, \mathrm{S}, \mathrm{Mn}, \mathrm{Zn}$ & $\mathrm{K}, \mathrm{S}, \mathrm{Mn}, \mathrm{Zn}$ & - \\
\hline Cinnamic acid deri & $(\mathrm{Fe})$ & $(\mathrm{Mg}),(\mathrm{Fe})$ & $\mathrm{Mg}$ \\
\hline Rosmarinic & $\mathrm{K}, \mathrm{Mn}$, & $\mathrm{Ca}, \mathrm{Mn}, \mathrm{Zn}$ & $\mathrm{K}, \mathrm{Mn}, \mathrm{Zn}$ \\
\hline (MPP) & $\mathrm{P}, \mathrm{K}, \mathrm{Ca}, \mathrm{B}, \mathrm{Fe}, \mathrm{Mn}$ & $\mathrm{P}, \mathrm{K}, \mathrm{Ca}$ & $\mathrm{Ca}, \mathrm{B}, \mathrm{Fe}, \mathrm{Mn}$ \\
\hline${ }^{2} \mathrm{Pol}$ & P11) as described i & d Scagel $(2009,20$ & $\begin{array}{l}\text { MPP }=\text { sum of } \mathrm{P} 2- \\
\text { and leaves). } \\
\text { an's } R \text { at } P \leq 0.05 \text {; }\end{array}$ \\
\hline
\end{tabular}

(Copetta et al., 2006). These two studies used different methods for quantifying AMF colonization, different basil cultivars, different AMF, and were 6 to 8 weeks shorter than our study. AMF colonization can be sensitive to nutrient availability (particularly P) in the growing substrate (Fernández et al., 2011). The $P$ rates used in our experiment were selected, based on previous experience with this AMF isolate, in an effort to minimize their potential for impact on AMF colonization. $\mathrm{P}$ rate had no significant influence on colonization; thus, the influence of $\mathrm{P}$ rate on growth and composition in AMF-inoculated plants is not confounded by differences in colonization.

Beneficial and pathogenic bacteria and fungi in the rhizosphere and the compounds they produce can alter plant secondary metabolism (Kim et al., 2003, 2006; Toussaint et al., 2007). The AMF inoculum used in this study consisted of spores and root fragments from pot cultures of onion. Therefore, although non-inoculated plants were not colonized by AMF, any effects of AMF inoculation on growth and composition of basil need to be interpreted as a response to AMF and other rhizosphere organisms from the pot culture inoculum.

Cultivar variation. The among-cultivar variation accounted for greater than $60 \%$ for most variables measured (e.g., biomass, nutrients, and phenolics) in our study. The amongcultivar variation for most variables measured in our study was substantially greater than the variation associated with either AMF or P rate effects. Basil cultivars accumulate biomass at different rates and in different structures depending on growing environment (Beaman et al., 2009; Zheljazkov et al., 2008a). High among-cultivar variation in growth can complicate interpretation of composition data based solely on concentration or content alone. Production and composition of phenolics in basil can vary substantially among cultivars (Kwee and Niemeyer, 2011). The four cultivars in our experiment were randomly selected from a large number of commercially available cultivars; thus, the among-cultivar growth variation in one growing environment broadens the inference of the effects of treatments on basil growth and composition.

Plant growth and biomass allocation. AMF inoculation and increased $\mathrm{P}$ rate had different effects on growth and biomass allocation in basil. AMFs have been previously reported to increase or have no influence on total growth of basil and differentially affect growth of specific structures (Copetta et al., 2006; Lee and Scagel, 2009; Toussaint et al., 2007). Decreased total plant biomass and increased root growth is a common plant response to low $\mathrm{P}$ availability in the growing substrate (Veresoglou et al., 2012). In our study, there was no significant interaction between $\mathrm{AMF}$ and $\mathrm{P}$ rate treatments on biomass or biomass allocation. Inoculation with AMF increased biomass but had no influence on biomass allocation. In contrast, $\mathrm{P}$ rate increased biomass and altered biomass allocation. Additionally, AMF inoculation accounted for a greater proportion of variation in root, stem, and total plant biomass than $\mathrm{P}$ rate. These results suggest that the influence of AMF on growth may not be completely related to plant P status.

Nutrient uptake and allocation. Greater P rate increased biomass, $\mathrm{P}$ concentration, and $P$ content of basil and there was no interaction between $\mathrm{P}$ rate and AMF inoculation on biomass, $\mathrm{P}$ concentration, and $\mathrm{P}$ content. These results indicate that non-mycorrhizal and AMF plants grown with the low $\mathrm{P}$ rate were $\mathrm{P}$ deficient compared with high $\mathrm{P}$ plants and increasing $\mathrm{P}$ rate enhanced $\mathrm{P}$ uptake (e.g., plants were more efficient at $\mathrm{P}$ uptake). In contrast, AMF inoculation increased biomass and $\mathrm{P}$ content but not $\mathrm{P}$ concentration indicating that AMF only increased $\mathrm{P}$ accumulation in the plant and not the ability of basil to absorb P. Araim et al. (2009) reported that AMF inoculation increased $P$ concentration of shoots but not roots of coneflower [Echinacea purpurea (L.) Monech.]. Mycorrhizal fungi are reported to improve $\mathrm{P}$ uptake in low $\mathrm{P}$ growing conditions, primarily because the fungi's extraradical hyphae increase access to $\mathrm{P}$ by extending beyond the P-depletion zone around the root system (Smith et al., 2003). When there is no response to AMF in terms of $\mathrm{P}$ uptake, it has been assumed that the mycorrhizal uptake pathway is not functioning and that all of the plant $\mathrm{P}$ is absorbed directly through $\mathrm{P}$ transporters in the root epidermis and root hairs. Increased growth or success of AMF-colonized plants is then attributed to other benefits of the symbiosis. In a container, extraradical hyphae may not improve physical access to $\mathrm{P}$ beyond that of non-mycorrhizal roots; however, Smith et al. (2003) believe that AMFs are a dominant route for plant $\mathrm{P}$ supply, even when overall growth or $\mathrm{P}$ uptake remains unaffected.

AMF inoculation and increased $P$ rate had different effects on nutrient uptake in basil. AMF inoculation of basil enhanced N, K, S, $\mathrm{B}, \mathrm{Fe}$, and $\mathrm{Zn}$ uptake suggesting that AMFinoculated plants were either more efficient at uptake of these nutrients or had a higher demand for these nutrients. In our study, AMF increased accumulation or enhanced uptake of all nutrients. In contrast, increased $\mathrm{P}$ rate enhanced uptake of fewer nutrients and even suppressed uptake of $\mathrm{Cu}$ and S. Mycorrhizal fungi have been reported to improve uptake of several nutrients, including N, P, K, S, Ca, and Zn (Azcón et al., 2003; Clark and Zeto, 2000). Reports of enhanced nutrient uptake in AMF-inoculated plants are not always substantiated by analyses of total plant nutrient uptake (e.g., only leaf concentrations are measured) and even when total plant uptake is calculated, concentration data are not always used to distinguish whether nutrient uptake was enhanced (e.g., increased concentration and content) or just increased as a result of greater biomass in AMF-inoculated plants.

Enhanced $\mathrm{P}$ and $\mathrm{Ca}$ uptake in high $\mathrm{P}$ plants compared with low $\mathrm{P}$ plants resulted in enhanced accumulation of these nutrients as well as $\mathrm{B}$ and $\mathrm{Fe}$ in shoots and $\mathrm{Fe}$ and $\mathrm{Mg}$ in roots. Additionally, increased $\mathrm{P}$ rate suppressed accumulation of $\mathrm{S}$ and $\mathrm{Cu}$ in roots. These results indicate $\mathrm{P}$ availability alters nutrient accumulation patterns in basil and suggest that $P$ rate alters the ability of plants to use nutrients for growth and metabolic processes. Plants adapt their morphology and metabolism in response to P-limiting growing conditions (Rausch and Bucher, 2002). These adaptive changes strive to increase $\mathrm{P}$ availability in the rhizosphere, enhance $\mathrm{P}$ uptake, and maintain metabolic efficiency. In our study, $\mathrm{P}$ availability influenced biomass allocation so it is not surprising that it also influenced allocation of nutrients within the plant. In contrast, enhanced N, K, S, $\mathrm{B}, \mathrm{Fe}$, and $\mathrm{Zn}$ uptake in AMF-inoculated plants compared with non-inoculated plants resulted in enhanced accumulation of these nutrients in shoots and enhanced accumulation of all these nutrients except $\mathrm{Fe}$ in roots. These results indicate that AMF had little effect on nutrient accumulation or allocation patterns in basil and did not alter the ability of plants to use nutrients in the same manner as increased $\mathrm{P}$ rate. 
Plant growth effects on phenolics. Inoculation with AMF and increasing $\mathrm{P}$ rate had similar effects on the production of TPs and rosmarinic acid (P11), the main polyphenolic detected in basil in the study. The effects of AMF and $\mathrm{P}$ rate on TPs and rosmarinic acid production were related to the effects of treatments on plant size. Both AMF inoculation and greater $\mathrm{P}$ rate increased plant biomass, TP content, and rosmarinic acid content but not their concentration. These results indicate TP and rosmarinic acid concentrations were not enhanced by either AMF inoculation or $\mathrm{P}$ rate. Others have reported that AMF inoculation increased TPs in lettuce and P fertilizer source had no influence on TP production in non-mycorrhizal plants but increased TP production in AMF-inoculated plants (Baslam et al., 2011). Toussaint et al. (2007) reported that increased $\mathrm{P}$ rate increased shoot and root concentrations of rosmarinic acid in nonmycorrhizal $O$. basilicum 'Genova' and inoculation with $R$. intraradices had no influence on rosmarinic acid concentrations. Their study did not report total plant $\mathrm{P}$ uptake, rosmarinic acid production, or the influence of $\mathrm{P}$ rate on biomass allocation. In our study, increased $P$ rate enhanced accumulation of rosmarinic acid in shoots but not total plant production of rosmarinic acid because of decreased rosmarinic acid and biomass allocation to roots. The plants in our study were older than those used by Toussaint et al. (2007). Differences in plant age between the two studies may account for differences in response of rosmarinic acid in roots to $\mathrm{P}$ rate.

Inoculation with AMF and increasing $\mathrm{P}$ rate differentially increased total plant accumulation of several other phenolics as a result of treatment effects of plant size. For example, the effects of AMF inoculation on content of cinnamyl malic acid (P3), caffeic acid derivative $(\mathrm{P} 8)$, and quercetin-rutinoside $(\mathrm{P} 9)$ and the effects of $\mathrm{P}$ rate on content on caftaric acid (P2) and feruloyl tartaric acid (P4) were primarily a function of differences in plant size between treatments. Copetta et al. (2006) tested three AMFs (F. mosseae BEG 12, Gigaspora margarita BEG 34, and Gi. rosea BEG 9) and demonstrated AMF altered essential oil composition of 'Genovese' basil depending on the AMF isolated used for inoculation. The authors suggested that the increase in essential oil production in Gi. roseainoculated plants may have been linked to greater plant biomass (Copetta et al., 2006). When plant growth increases and more photosynthates are produced as a result of improved nutrition, phenolic concentrations will increase as a result of allocation of excess fixed carbon to the shikimic acid pathway (Haukioja et al., 1998). Some of the conflicting statements in the literature concerning the effects of fertilizer rates and AMF on phenolic production may be a result differences in concentration not being interpreted in conjunction with biomass data.

Phenolics influenced by arbuscular mycorrhizal fungus and phosphorus rate. Both increased $\mathrm{P}$ rate and AMF inoculation enhanced production (increased biomass, concentration, and content) of certain phenolics resulting in enhanced production of MPP. Both AMF inoculation and increased $\mathrm{P}$ rate enhanced production of caffeic acid derivative (P6) and chicoric acid (P7), two polyphenolics only produced in shoots. Caffeic acid derivative (P6) was first quantified in basil by Lee and Scagel (2009). The presence of chicoric acid, the main polyphenolic found in coneflower (Lee and Scagel, 2010; Mølgaard et al., 2003), was recently reported in basil (Lee and Scagel, 2009). Chicoric acid is purportedly one of the numerous a.i. (alkamides, other caffeic acid derivatives, polysaccharides, and glycoproteins) associated with human health benefits from coneflower dietary supplements (Barnes et al., 2005). Araim et al. (2009) reported that inoculation with AMF increased chicoric acid in coneflower roots. Chicoric acid was not detected in roots of basil, but AMF increased shoot production of chicoric acid.

The differential effects of $\mathrm{P}$ rate and AMF inoculation on other specific polyphenolics resulted in treatments altering the phenolic composition in the whole plant, shoots, and roots. To date, most studies reporting the influence of AMF or fertilizer rate on phenolics have only reported accumulation or just concentrations in leaves (Geneva et al., 2010; Nguyen et al., 2010) and not determined whole plant production (Nell et al., 2009).

Phenolics influenced only by phosphorus rate. Differences in cinnamyl malic acid ( $\mathrm{P} 3)$, caffeic acid derivative (P8), and quercetinrutinoside (P9) accumulation between noninoculated and AMF-inoculated plants were related to differences in growth (e.g., increased content but not concentration). In contrast, increasing $\mathrm{P}$ rate enhanced the production of these polyphenolics (e.g., increased concentration and content). Enhanced production of cinnamyl malic acid, chicoric acid (P7), caffeic acid derivative (P8), and quercetin-rutinoside in high $\mathrm{P}$ plants compared with low P plants was a result of enhanced accumulation of these nutrients in shoots (these compounds were only detected in shoots). These results indicate $\mathrm{P}$ availability alters phenolic accumulation patterns in basil and suggest that $\mathrm{P}$ rate alters the plant requirements for specific secondary metabolites, particularly in shoots

Cinnamic acid derivatives have been found in basil (Jayasinghe et al., 2003); however, the compounds reported were not identified as a cinnamyl malic acid per se. Lee and Scagel (2009) detected a cinnamyl malic acid (P3; esterified conjugate of cinnamic acid and malic acid) in basil shoots, and inoculation with AMF had no influence on cinnamyl malic acid content. Conjugates of cinnamic acid are extremely widespread in the plant kingdom and esterified malic acid conjugates have been identified in many plants and plant products, including stone fruit, radish, spinach, chicory, and lettuce (Clifford, 1999; Winter and Herrmann, 1986). It is speculated that these types of phenolics may play roles in plant defenses against pathogens, insects, and ultraviolet damage and alter product quality (digestibility) of forage crops (Sullivan and Zarnowski, 2011).

Caffeic acid derivative (P8; lithospermic acid $\mathrm{A}$ isomer, a conjugate of caffeic and rosmarinic acids) was first quantified in fresh basil by Lee and Scagel $(2009,2010)$. Caffeic acid derivative (P8) has also been found in roots and rhizomes of Salvia miltiorrhiza Bunge (Chinese herb: danshen) (Guo et al., 2007) and in dried products of basil and coneflower (Lee and Scagel, 2010). Quercetinrutinoside (P9) has been found in several plant species including basil (Lee and Scagel, 2009, 2010) and ingestion of this compound is linked to cardiovascular health (Serra et al., 2012). Perner et al. (2008) reported that $\mathrm{N}$ fertilizer type altered quercetin-glycoside production of onion and inoculation with AMF increased content of specific quercetin-glycosides in bulbs.

Increased $\mathrm{P}$ rate suppressed production of caffeic acid (P5) and accumulation of caffeic acid in roots but not shoots. Suppressed net caffeic acid accumulation in roots may be related to increased root exudation of phenolic acids in response to $\mathrm{P}$ availability. Others have reported that roots exude caffeic acid in low nutrient environments to improve rhizosphere chemistry for optimal nutrient uptake (Dakora and Phillips, 2002). Increasing P rate has been reported to increase root concentrations of caffeic acid in non-mycorrhizal 'Genova' (Toussaint et al., 2007). Total plant production was not reported by Toussaint et al. (2007), so it is unclear whether plants produced more caffeic acid at greater $P$ rates. Several researchers have reported negative correlations between concentrations of secondary compounds and plant growth rate or nutrient concentrations in plants (Haukioja et al., 1998). This occurs because growth processes dominate over the production of secondary compounds and $\mathrm{C}$ is available for secondary compounds only when plant growth is restricted by a lack of mineral nutrients or other factors. Many polyphenolics such as rosmarinic, chicoric, and caftaric acids are derivatives of caffeic acid (Boudet, 2007). In our study, increased $P$ rate suppressed production or accumulation of caffeic acid but increased or had no effect on the derivatives from this precursor. The effect of $\mathrm{P}$ rate on caffeic acid production may be a response to stress when plants are grown with lower P availability (e.g., P deficiency increased production) (Dixon and Paiva, 1995) or a result of increased root exudation of caffeic acid in plants grown with higher $\mathrm{P}$ availability (Mandal et al., 2010; Marschner, 1995).

Phenolics influenced only by arbuscular mycorrhizal fungus. AMF inoculation enhanced total plant production of caftaric acid (P2), a polyphenolic only detected in shoots, and feruloyl tartaric acid (P4) and caffeic acid (P5), polyphenolics detected in shoots and roots. Enhanced caftaric acid, tartaric acid, caffeic acid, caffeic acid (P6), and chicoric acid (P7) production in AMF-inoculated plants compared with non-inoculated plants resulted in enhanced accumulation of these polyphenolics in shoots (all) and roots (only feruloyl 
tartaric acid and caffeic acid in roots). These results indicate that AMF had little effect on accumulation patterns for several polyphenolics in basil and did not alter plant requirements for these specific secondary metabolites. In contrast, although AMF had no influence on net production of rosmarinic acid (P11), AMF suppressed rosmarinic acid accumulation in roots. This may be a result of rosmarinic acid exudation from roots or decreased metabolic requirements for rosmarinic acid in response to the presence of the fungus in the root system. Others have reported that fungal and bacterial pathogens can increase production and exudation of rosmarinic acid from roots (Bais et al., 2006).

To our knowledge, our results are the first report of AMF enhancing production of caftaric and feruloyl tartaric acids in basil. Caftaric acid is produced in several plants, including coneflower and basil (Lee and Scagel, 2010). Araim et al. (2009) reported that inoculation with $R$. intraradices decreased caftaric acid in shoots and increased caftaric acid in roots of coneflower. Caftaric acid was not detected in roots of basil, but AMF increased shoot production of caftaric acid. Toussaint et al. (2007) reported that inoculation with $G$. calendonium (Nicolson \& Gerd.) Trappe \& Gerd. and F. mosseae increased caffeic acid concentrations in 'Genova' shoots and inoculation with $R$. intraradices has no influence on shoot caffeic acid concentrations. Araim et al. (2009) reported that AMF increased production of most phenolics in roots and suggested that mycorrhizae could play an important role in optimizing the growth of coneflower by inducing the production of secondary phytomedicinal metabolites. Plants produce several phenolics in response to biotic and abiotic factors (Bennett and Wallsgrove, 1994; ChalkerScott, 1999). Chitin, a component of fungal cell walls, can induce production of secondary metabolites in basil (Kim et al., 2003). Little is known about signaling compounds such as chitin and the role of secondary metabolism in the interactions between plants and mycorrhizae (Strack and Fester, 2006; Strack et al., 2003).

Relationships between nutrient uptake and phenolics. Positive relationships between certain nutrients and phenolic production were a function of growth or allocation. For example $\mathrm{K}$ and $\mathrm{Zn}$ uptake was related to rosmarinic acid production, and AMF increased $\mathrm{K}$ and Zn uptake; however, AMF only enhanced rosmarinic acid accumulation in shoots not roots. Correlations between nutrient uptake and phenolics do not imply direct linkage between nutrients and phenolic production; however, these relationships can give insight into how nutrient management may impact product qualities. Nguyen et al. (2010) reported that increased $\mathrm{K}$ fertilizer application rate increased phenolic concentrations in leaves of 'Sweet Thai', 'Dark Opal', and 'Genovese' basil plants. They did not measure the influence of $\mathrm{K}$ rate on root phenolics.

Positive correlations between certain nutrients and phenolic production may be related to the impact of these nutrients on phenolic metabolism. For example, the biosynthesis of phenolics is closely related with $\mathrm{N}$ metabolism, because the precursors for all phenolics are phenylalanine and tyrosine (Boudet, 2007; Petersen et al., 2009; Vogt, 2010). The influence of AMF and $\mathrm{P}$ rate on phenolic composition was related to the effects of treatments on different nutrients. For example, the influence of AMF on phenolic composition was related to the effects of AMF on enhanced $\mathrm{N}$, $\mathrm{S}, \mathrm{Mg}$, and $\mathrm{B}$ uptake and the influence of $\mathrm{P}$ rate on phenolic composition was related to the effects of $\mathrm{P}$ rate on enhanced uptake of $\mathrm{P}$ and $\mathrm{Ca}$. Nitrogen and $\mathrm{S}$ fertilizer have been shown to be useful management tools for altering basil essential oil content and composition (Zheljazkov et al., 2008b). Nguyen and Niemeyer (2008) reported that increased $\mathrm{N}$ fertilizer application rate decreased concentrations of rosmarinic acid and caffeic acid in two of the three basil cultivars evaluated. In our study, $\mathrm{N}$ uptake was not related to rosmarinic acid (P11) or caffeic acid (P5) production or shoot accumulation. Nguyen and Niemeyer (2008) used much younger plants than those in our study and they did not report effects of $\mathrm{N}$ application on root composition or account for effects of growth on concentrations.

The influence of AMF and $\mathrm{P}$ rate on production of specific polyphenolics was not related to nutrient uptake. For example, AMF inoculation enhanced production of caffeic acid derivative (P6); however, enhanced production was not related to AMF-enhanced uptake of nutrients. The effects of $P$ rate on certain phenolics were not related to either plant size or uptake of nutrients. For example, increased $\mathrm{P}$ rate enhanced quercetinrutinoside (P9) accumulation and the effects of $P$ rate on quercetin-rutinoside were not related to the effects of $\mathrm{P}$ rate on plant size or uptake of any measured nutrient. Plant nutrient status can significantly influence or have little or no effect on production secondary metabolites (Areias et al., 2000; Fanasca et al., 2006; Mogren et al., 2006; Nell et al., 2009). Our results suggest that conflicting reports of the influence of nutrition on phenolic production may be a result of the specific phenolics measured, the impact of nutrition on growth and allocation, and the use of making inferences from data derived from only aerial portions of a plant.

In conclusion, our results indicate fertilizer management can be used to alter phenolic composition of basil plants and AMF inoculation may provide an additional strategy for optimizing basil composition quality beyond benefits obtained from just altering plant nutrient status or growth. For example, improving $\mathrm{N}, \mathrm{S}, \mathrm{Mg}$, and $\mathrm{B}$ nutrition by $\mathrm{AMF}$ inoculation may enhance accumulation of caftaric, feruloyl tartaric, and caffeic acids. In contrast, improving $\mathrm{P}$ and $\mathrm{Ca}$ nutrition by altering $\mathrm{P}$ rate may enhance accumulation of cinnamyl malic acid and caffeic acid derivative $(\mathrm{P} 8)$. Our results also indicate that increasing $\mathrm{P}$ rate or AMF inoculation may enhance accumulation of chicoric acid; however, the effects of $\mathrm{P}$ rate and AMF on enhanced accumulation of chicoric acid was not related to enhanced uptake of similar nutrients.

\section{Literature Cited}

Araim, G., A. Saleem, J.T. Arnason, and C. Charest. 2009. Root colonization by an arbuscular mycorrhizal (AM) fungus increases growth and secondary metabolism of purple coneflower, Echinacea purpurea (L.). Monech. J. Agr. Food Chem. 57:2255-2258.

Areias, F., P. Vanentao, P.B. Andrade, F. Ferreres, and R.M. Seabra. 2000. Flavonoids and phenolic acids of sage: Influence of some agricultural factors. J. Agr. Food Chem. 48:6081-6084.

Azcón, R., E. Ambrosano, and C. Charest. 2003. Nutrient acquisition in mycorrhizal lettuce plants under different phosphorus and nitrogen concentration. Plant Sci. 165:1137-1145.

Bais, H.P., T.L. Weir, L.G. Perry, S. Gilroy, and J.M. Vivanco. 2006. The role of root exudates in rhizosphere interactions with plants and other organisms. Annu. Rev. Plant Biol. 57:233-266.

Barnes, J., L.A. Anderson, S. Gibbons, and J.D. Philipson. 2005. Echinacea species [Echinacea angustifolia (DC.) Hell., Echinacea pallida (Nutt.) Nutt., Echinacea purpurea (L.) Moench]: A review of their chemistry, pharmacology, and clinical properties. J. Pharm. Pharmacol. 57:929-954.

Baslam, M., I. Pascual, M. Sánchez-Díaz, J. Erro, J.M. García-Mina, and N. Goicoechea. 2011. Improvement of nutritional quality of greenhouse-grown lettuce by arbuscular mycorrhizal fungi is conditioned by the source of phosphorus nutrition. J. Agr. Food Chem. 59:1112911140 .

Beaman, A.R., R.J. Gladon, and J.A. Schrader. 2009. Sweet basil requires an irradiance of 500 $\mu \mathrm{mol} \cdot \mathrm{m}^{-2} \cdot \mathrm{s}^{-1}$ for greatest edible biomass production. HortScience 44:64-67.

Bennett, R.N. and R.M. Wallsgrove. 1994. Secondary metabolites in plant defense mechanisms. New Phytol. 127:617-633.

Bierman, B.J. and R.G. Linderman. 1980. Quantifying vesicular-arbuscular mycorrhizae: A proposed method towards standardization. New Phytol. 87:63-67.

Boudet, A.M. 2007. Evolution and current status of research in phenolic compounds. Phytochemistry 68:2722-2735.

Brewer, M. 2011. Natural antioxidants: Sources, Compounds, mechanisms of action, and potential applications. Compr. Rev. Food Sci. Food Safety 10:221-247.

Chalker-Scott, L. 1999. Environmental significance of anthocyanins in plant stress response. Photochem. Photobiol. 70:1-9.

Clark, R.B. and S.K. Zeto. 2000. Mineral acquisition by arbuscular mycorrhizal plants. J. Plant Nutr. 23:867-902.

Clifford, M.N. 1999. Chlorogenic acids and other cinnamates-Nature, occurrence and dietary burden. J. Sci. Food Agr. 79:362-372.

Copetta, A., G. Lingua, and G. Berta. 2006. Effects of three AM fungi on growth, distribution of glandular hairs, and essential oil production in Ocimum basilicum L. var. Genovese. Mycorrhiza 16:485-494

Dakora, F.D. and D.A. Phillips. 2002. Root exudates as mediators of mineral acquisition in lownutrient environments. Plant Soil 245:35-47.

Dixon, R.A. and N.L. Paiva. 1995. Stress-induced phenyl propanoid metabolism. Plant Cell 7: 1085-1097.

Dragland, S., H. Senoo, K. Wake, K. Holte, and R. Blomhoff. 2003. Several culinary and medicinal herbs are important sources of dietary antioxidants. J. Nutr. 133:1286-1290. 
Fanasca, S., G. Colla, G. Maiani, E. Venneria, Y. Rouphael, E. Azzini, and F. Saccardo. 2006. Changes in antioxidant content of tomato fruits in response to cultivar and nutrient solution composition. J. Agr. Food Chem. 54:4319-4325.

Fernández, M.C., F. Hernán, G. Boem, and G. Rubio. 2011. Effect of indigenous mycorrhizal colonization on phosphorus-acquisition efficiency in soybean and sunflower. J. Plant Nutr. Soil Sci. 174:673-677.

Fester, T., W. Maier, and D. Strack. 1999. Accumulation of secondary compounds in barley and wheat roots in response to inoculation with an arbuscular mycorrhizal fungus and coinoculation with rhizosphere bacteria. Mycorrhiza 8:241-246.

Freire, C.M.M., M.O.M. Marques, and M. Costa. 2006. Effects of seasonal variation on the central nervous system activity of Ocimum gratissium L. essential oil. J. Ethnopharmacol. 105:161166.

Ganz, T.R., S.G. Kailis, and L.K. Abbott. 2002, Mycorrhizal colonization and its effect on growth phosphorus uptake and tissue phenolic content in the European olive (Olea europaea L.). Adv. Hort. Sci. 16:109-116.

Geneva, M.P., I.V. Stancheva, M.M. Boychinova, M.H. Mincheva, and P.A. Yonova. 2010. Effects of foliar fertilization and arbuscular mycorrhizal colonization on Salvia officinalis L. growth, antioxidant capacity, and essential oil composition. J. Sci. Food Agr. 99:686-702.

Gianinazzi, S., A. Gollotte, M.-N. Binet, D. van Tuinen, D. Redecker, and D. Wipf. 2010. Agroecology: The key role of arbuscular mycorrhizas in ecosystem services. Mycorrhiza 20:519-530.

Guo, Y., D. Zhang, H. Wang, Z. Xiu, L. Wang, and H. Xiao. 2007. Hydrolytic kinetics of lithospermic acid B extracted from roots of Salvia miltiorrhiza. J. Pharm. Biomed. Anal. 43:435439.

Gutierrez, J., C. Barry-Ryan, and P. Bourke. 2008. The antimicrobial efficacy of plant essential oil combinations and interactions with food ingredients. Intl. J. Food Microbiol. 124:91-97.

Haase, D.L. and R. Rose. 1995. Vector analysis and its use for interpreting plant nutrient shifts in response to silvicultural treatments. For. Sci. 41:54-66.

Haukioja, E., V. Ossipov, J. Koricheva, T. Honkanen, S. Larsson, and K. Lempa. 1998. Biosynthetic origin of carbon-based secondary compounds: Cause of variable responses of woody plants to fertilization? Chemoecology 8:133139.

Hossian, M.B., D.K. Fai, N.P. Brunton, A.B. Martin-Diana, and C. Barry-Ryan. 2010. Characterization of phenolic composition in Lamiaceae spices by LC-ESI-MS/MS. J. Agr. Food Chem. 58:10576-10581.

Hussain, A.I., F. Anwar, S. Sherazi, and R. Przybylski. 2008. Chemical composition, antioxidant and antimicrobial activities of basil (Ocimum basilicum) essential oils depends on season variations. Food Chem. 108:986-995.

Javanmardi, J., A. Khalighi, A. Kashi, H.P. Bais, and J.M. Vivanco. 2002. Chemical characterization of basil (Ocimum basilicum L.) found in local accessions and used in traditional medicines in Iran. J. Agr. Food Chem. 50:5878-5883.

Jayasinghe, C., N. Gotoh, T. Aoki, and S. Wada. 2003. Phenolics composition and antioxidant activity of sweet basil (Ocimum basilicum L.). J. Agr. Food Chem. 51:4442-4449.

Kim, H.-Y., F. Chen, Z. Wang, and N. Rajapakse. 2003. Effect of chitosan on the biological properties of sweet basil. J. Agr. Food Chem. 53:3696-3701.
Kim, H.-Y., F. Chen, Z. Wang, and N. Rajapakse. 2006. Effect of methyl jasmonate on secondary metabolites of sweet basil (Ocimum basilicum L.). J. Agr. Food Chem. 54:2327-2332.

Kwee, E.M. and E.D. Niemeyer. 2011. Variations in phenolic composition and antioxidant properties among fifteen basil (Ocimum basilicum L.) cultivars. Food Chem. 128:1044-1050.

Lee, J. 2010. Caffeic acid derivatives in dried Lamiaceae and Echinacea purpurea products. J. Funct. Foods. 2:158-162.

Lee, J., R.W. Durst, and R.E. Wrolstad. 2005 Determination of total monomeric anthocyanin pigment content of fruit juice, beverages, natural colorants, and wines by the $\mathrm{pH}$ differential method: Collaborative study. J. AOAC Intl. 88:1269-1278.

Lee, J. and C.E. Finn. 2007. Anthocyanins and other polyphenolics in American elderberry (Sambucus canadensis) and European elderberry (S. nigra) cultivars. J. Sci. Food Agr. 87:2665-2675.

Lee, J. and C.F. Scagel. 2009. Chicoric acid found in basil (Ocimum basilicum L.) leaves. Food Chem. 115:650-656.

Lee, J. and C.F. Scagel. 2010. Chicoric acid levels in commercial basil (Ocimum basilicum) and Echinacea purpurea products. J. Funct. Foods. 2:77-84.

Li, Z., X. Wang, F. Chen, and H.-J. Kim. 2007. Chemical changes and over expressed genes in sweet basil (Ocimum basilicum L.) upon methyl jasmonates treatment. J. Agr. Food Chem. 55: 706-713.

Li, Z., Z. Zhao, A.K. Sandhu, and L. Gu. 2010 Effects of exogenous abscisic acid on yield, antioxidant capacities, and phytochemical contents of greenhouse grown lettuces. J. Agr. Food Chem. 58:6503-6509.

Makri, O. and S. Kintzios. 2007. Ocimum sp. (basil): Botany, cultivar, pharmaceutical properties, and biotechnology. J. Herbs Spices Med. Plants 13:123-150.

Malusà, E.M., A. Russo, C. Mozzetti, and A. Belligno. 2006. Modification of secondary metabolism and flavonoid biosynthesis under phosphate deficiency in bean roots. J. Plant Nutr. 29:245-258.

Mandal, S.M., D. Chakraborty, and D. Satyahari. 2010. Phenolic acids act as signaling molecules in plant-microbe symbioses. Plant Signal. Behav. 5:359-368.

Marschner, H. 1995. Mineral nutrition of higher plants. Academic Press, San Diego, CA.

McGonigle, T.P., M.H. Miller, D.G. Evans, G.L. Fairchild, and J.A. Swan. 2006. A new method which gives an objective measure of colonization of roots by vesicular-arbuscular mycorrhizal fungi. New Phytol. 115:495-501.

Mogren, L.M., M.E. Olsson, and U.E. Gertsson. 2006. Quercetin content in field-cured onions (Allium cepa L.): Effects of cultivar, lifting time, and nitrogen fertilizer level. J. Agr. Food Chem. 54:6185-6191.

Mølgaard, P., J. Søren, P. Christensen, and C. Cornett. 2003. HPLC method validated for the simultaneous analysis of chichoric acid and alkamides in Echinacea purpurea plants and products. J. Agr. Food Chem. 51:69226933.

Nell, M., M. Vötsch, H. Vierheilig, S. Steinhellner, K. Zitterl-Eglseer, C. Franz, and J. Novak. 2009. Effect of phosphorus uptake on growth and secondary metabolites of garden sage (Salvia officinalis L.). J. Sci. Food Agr. 80: 1090-1096.

Nguyen, P.M., E.M. Kwee, and E.D. Niemeyer. 2010. Potassium rate alters the antioxidant capacity and phenolic concentration of basil (Ocimum basilicum L.) leaves. Food Chem. 123: 1235-1241.

Nguyen, P.M. and E.D. Niemeyer. 2008. Effects of nitrogen fertilization on the phenolic composition and antioxidant properties of basil (Ocimum basilicum L.). J. Agr. Food Chem. 56: 8685-8691.

Perner, H.S., G. Rohn, N. Driemel, D. Batt, L. Schwarz, W. Kroh, and E. George. 2008. Effect of nitrogen species supply and mycorrhizal colonization on organosulfur and phenolic compounds in onion. J. Agr. Food Chem. 56: 3538-3545.

Petersen, M., Y. Abdullah, J. Benner, D. Eberle, K. Gehlen, S. Hücherig, V. Janiak, K.H. Kim, M. Sander, C. Weitzel, and S. Wolters. 2009. Evolution of rosmarinic acid biosynthesis. Phytochemistry 70:1663-1679.

Philips, J.M. and D.S. Hayman. 1970. Improved procedures for clearing roots and staining parasitic and vesicular-arbuscular mycorrhizal fungi for rapid assessment of infection. Trans. Br. Mycol. Soc. 55:158-161.

Rausch, C. and M. Bucher. 2002. Molecular mechanisms of phosphate transport in plants. Planta 216:23-37.

Scagel, C.F., G. Bi, L.H. Fuchigami, and R.P. Regan. 2007. Seasonal variation in growth, nitrogen uptake and allocation by containergrown evergreen and deciduous Rhododendron cultivars. HortScience 42:1440-1449.

Scagel, C.F., G. Bi, L.H. Fuchigami, and R.P. Regan. 2008. Nitrogen availability alters mineral nutrient uptake and demand in containergrown deciduous and evergreen Rhododendron. J. Environ. Hort. 26:177-187.

Serra, A., A. Macià, M.-P. Romero, J. Reguant, N. Ortega, and M.-J. Motilva. 2012. Metabolic pathways of the colonic metabolism of flavonoids (flavonols, flavones, and flavanones) and phenolic acids. Food Chem. 130:383-393.

Smith, S., F.A. Smith, and I. Jacobsen. 2003. Mycorrhizal fungi can dominate phosphate supply to plants irrespective of growth responses. Plant Physiol. 133:16-20.

Strack, D. and T. Fester. 2006. Isoprenoid metabolism and plastid reorganization in arbuscular mycorrhizal roots. New Phytol. 172:22-34.

Strack, D., T. Fester, B. Hause, W. Schliemann, and M.H. Walter. 2003. Arbuscular mycorrhiza: Biological, chemical, and molecular aspects. J. Chem. Ecol. 29:1955-1979.

Sullivan, M.L. and R. Zarnowski. 2011. Red clover HCT2, a hydroxycinnamoyl-coenzyme A: Malate hydroxycinnamoyl transferase, plays a crucial role in biosynthesis of phaselic acid and other hydroxycinnamoyl-malate esters in vivo. Plant Physiol. 155:1060-1067.

Swift, K.I. and R.P. Brockley. 1993. Evaluating the nutrient status and fertilization response potential of planted spruce in the interior of British Columbia. Can. J. For. Res. 24:594-602.

Toussaint, J.P. 2007. Investigating physiological changes in the aerial parts of AM plants: What do we know and where should we be heading? Mycorrhiza 17:349-353.

Toussaint, J.P., F.A. Smith, and S.E. Smith. 2007. Arbuscular mycorrhizal fungi can induce the production of phytochemicals in sweet basil irrespective of phosphorus nutrition. Mycorrhiza 17:291-297.

Valentine, D.W. and H.L. Allen. 1990. Foliar responses to fertilization identify nutrient limitations in loblolly pine. Can. J. For. Res. 20:144-151.

Veresoglou, S.D., G. Menexes, and M.C. Rillig. 2012. Do arbuscular mycorrhizal fungi affect the allometric partition of host plant biomass to 
shoots and roots? A meta-analysis of studies from 1990 to 2010. Mycorrhiza 22:227-235.

Vogt, T. 2010. Phenylpropanoid biosynthesis. Mol. Plant. 3:2-20.

Waterhouse, A. 2002. Unit I1.1: Polyphenolics: Determination of total phenolics, p. 1-4. In: Wrolstad, R.E. (ed.). Current protocols in food analytical chemistry. John Wiley \& Sons, New York, NY.

Winter, M. and K. Herrmann. 1986. Esters and glucosides of hydroxycinnamic acids in vegetables. J. Agr. Food Chem. 34:616-620.

Woomer, P.L. 1994. Most probable number counts, p. 59-79. In: Weaver, R.W. (ed.). Methods of soil analysis, part 2. Soil Sci. Soc. Am., Inc. Madison, WI.

Yanishlieva, N.V., E. Marinova, and J. Pokorny. 2006. Natural antioxidants from herbs and spices. Eur. J. Lipid Sci. Technol. 108:776-793.

Yao, Q., H.H. Zhu, and R.S. Zeng. 2007. Role of phenolic compounds in plant defense: Induced by arbuscular mycorrhizal fungi. Allelopathy $\mathrm{J}$. 20:1-14.

Yi, W. and H.Y. Wetzstein. 2010. Biochemical, biological and histological evaluation of some culinary and medicinal herbs grown under greenhouse and field conditions. J. Sci. Food Agr. 90:1063-1070.
Yi, W. and H.Y. Wetzstein. 2011. Effects of drying and extraction conditions on the biochemical activity of selected herbs. HortScience 46:7073.

Zheljazkov, V.D., C.L. Cantrell, M.W. Ebelhar, D.E. Rose, and C. Coker. 2008a. Yield and composition of Ocimum basilicum L. and $\mathrm{Oci}$ mum sanctum $\mathrm{L}$. grown at four locations. HortScience 43:737-741.

Zheljazkov, V.D., C.L. Cantrell, M.W. Ebelhar, D.E. Rose, and C. Coker. 2008b. Productivity, oil content, and oil composition of sweet basil as a function of nitrogen and sulfur fertilization. HortScience 43:1415-1422. 